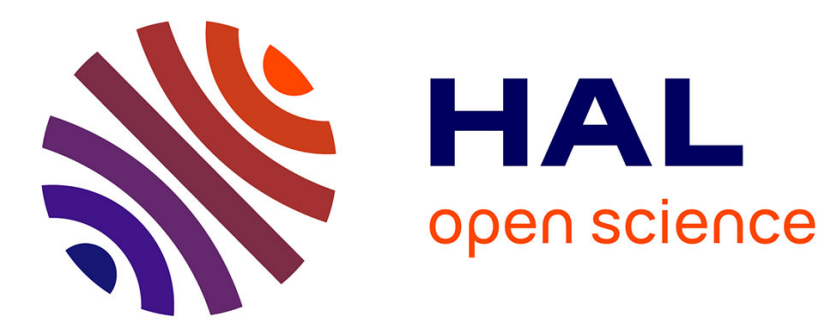

\title{
Chiral Tridentate-Based Ligands
}

Uchchhal Bandyopadhyay, Basker Sundararaju, Rinaldo Poli, Eric Manoury

\section{To cite this version:}

Uchchhal Bandyopadhyay, Basker Sundararaju, Rinaldo Poli, Eric Manoury. Chiral Tridentate-Based Ligands. Montserrat Diéguez. Chiral Ligands, 1, CRC Press, pp.167-194, 2021, 978-0-367-4-28488. 10.1201/9780367855734-5 . hal-03230854

\section{HAL Id: hal-03230854 https://hal.science/hal-03230854}

Submitted on 4 Jun 2021

HAL is a multi-disciplinary open access archive for the deposit and dissemination of scientific research documents, whether they are published or not. The documents may come from teaching and research institutions in France or abroad, or from public or private research centers.
L'archive ouverte pluridisciplinaire $\mathbf{H A L}$, est destinée au dépôt et à la diffusion de documents scientifiques de niveau recherche, publiés ou non, émanant des établissements d'enseignement et de recherche français ou étrangers, des laboratoires publics ou privés. 


\title{
Chapter 5: Chiral tridentate based ligands
}

\author{
ORCID ID \\ Uchchhal Bandyopadhyay : 0000-0002-1429-7373 \\ Basker Sundararaju : 0000-0003-1112-137X \\ Rinaldo Poli : 0000-0002-5220-2515 \\ Eric Manoury : 0000-0001-7991-8890
}

Uchchhal Bandyopadhyay, ${ }^{\mathrm{a}}$ Basker Sundararaju,${ }^{\mathrm{b}}$ Rinaldo Poli, ${ }^{\mathrm{a}}$ Eric Manoury ${ }^{\mathrm{a} *}$

a: CNRS, LCC (Laboratoire de Chimie de Coordination), Université de Toulouse, UPS, INPT, 205 Route de Narbonne, F-31077 Toulouse Cedex 4, France.

b: Department of Chemistry, Indian Institute of Technology Kanpur, Uttar Pradesh, India.

eric.manoury@1cc-toulouse.fr

\section{Chapter Abstract}

The most recent tridentate ligands of any coordination pattern which have been used in any reactions of asymmetric catalysis and showed the best efficiencies in term of catalytic activities and selectivities, in particular indeed enantioselectivities are presented in this chapter: N,N,N ligands like Pybim, IPO, Bopa or Boxmi ligands , P,N,N ligands like SpiroPAP and analogues, N,P,N ligands like phosphine-bisoxazolines, P,N,P ligands like imine-diphosphines, P,N,S ligands like SpiroSAP, N,N,O ligands like pseudodipeptides or BinThro ligands, O,N,O ligands like imine-diols, N,C;N ligands like Phebox or Phebim ligands and many other ones.

\subsection{Introduction:}

Although rarely described in the literature only twenty years ago, a very large amount of chiral tridentate ligands has been now developed and applied to numerous catalyzed reactions. Amongst all these ligands, we have elected to present in this chapter only the most recent and efficient ones, covering a large variety of the possible coordination patterns. Indeed, because of space limitations, many interesting ligands and valuable catalytic systems could not be included but we hope that this chapter will provide a useful overview of the available chiral tridentate ligands for the asymmetric catalysis.

\section{$5.2 \mathrm{~N}, \mathrm{~N}, \mathrm{~N}$ ligands}


The first successful family of chiral tridentate ligands belong to the Pybox family (Pybox for pyridinebis(oxazoline), see Figure 5.1), ${ }^{1,2,3}$ introduced in 1989 by Nishiyama et al., ${ }^{4}$ which have been successfully used in various reactions such as the Mukaiyama aldol reaction, in particular with $\mathrm{Cu}(\mathrm{II})$ catalysts, with main contributions from Evans and coworkers, ${ }^{5}$ the hydrosilylation of ketones mainly in combination with $\mathrm{Rh}(\mathrm{III}),{ }^{4,6,7}$ the cyclopropanation with $\mathrm{Ru}(\mathrm{II}),{ }^{8}$ the allylic oxidation with $\mathrm{Cu}(\mathrm{II}),{ }^{9,10}$ the Dields-Alder reaction with Sc(III) $)^{11,12,13}$ and several others. Pybox are now well established and privileged ligands, regularly used to develop new catalytic systems. ${ }^{14,15,16,17,18,19,20,21,22}$

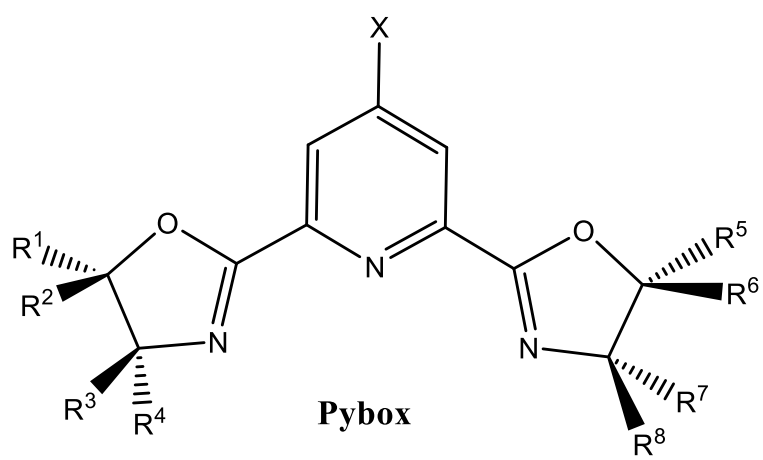

Figure 5.1: Pybox ligands

The Pybox structure has inspired the design of other chiral tridentate ligands, for instance by keeping the central pyridine part and replacing one or both oxazoline rings by other groups. In 2005, Beller et al. developed a new family of ligands called Pybim for pyridinebis(imidazoline) from various chiral 1,2-diamines (see figure 5.2). ${ }^{23}$ Ruthenium complexes of Pybim were tested in the asymmetric epoxidation of olefins by hydrogen peroxide: the chemoselectivities in epoxide were from low to excellent with moderate enatioselectivities (epoxide ee up to $71 \%$ for $t$-stilbene with ligands from $t$-stilbenediamine (figure 5.2, left structure with $\mathrm{R}=1$-naphtyloxy or (+)-menthyloxy). ${ }^{23}$ Pybim ligands were also used in the zinc-catalyzed hydrosilylation of acetophenone, although with low 
enantioselectivities $(\mathrm{ee}=16-24 \%){ }^{24}$<smiles>[R]N1C(c2cccc(C3=N[C@@H](c4ccccc4)[C@@H](F)N3[R])n2)=N[C@@H](c2ccccc2)[C@@H]1c1ccccc1</smiles><smiles>[R]N1C(c2cccc(C3=N[C@@H]4CCCC[C@H]4N3[R])n2)=N[C@@H]2CCCC[C@H]21</smiles>

\section{Pybim, $\mathbf{R}=\mathbf{H}$ or $-\mathbf{C}(\mathbf{O})-\mathbf{R}^{\prime}, \mathbf{R}^{\prime}$ beeing an alkyl, an aryl or an alkoxy group)}

Figure 5.2: Pybim ligands

Fernandez and Lassaletta developed new pyridinebis(hydrazones) (see Figure 5.3) and used them in the asymmetric Diels-Alder reaction of $\mathrm{N}$-crotonyloxazolidin-2-one with cyclopentadiene. $^{25}$ Good diastereoselectivities (endo/exo ratio up to 92/8) and enantioselectivities (ee up to 74\%) were obtained using ligand 5.3.c and $\mathrm{Cu}(\mathrm{OTf})_{2}$.

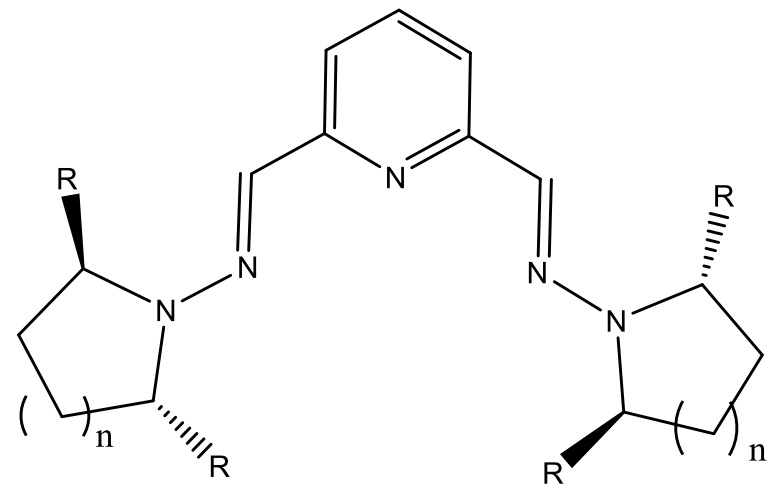

5.3.a: $R=P h, n=1 ;$ 5.3.b: $R=P h, n=2$; 5.3.c: $R=M e, n=1$

Figure 5.3: Pyridine bis(hydrazone) ligands

Pyrazoline-pyridine-oxazolines have been developed by $\mathrm{Yu}$ and coworkers for the ruthenium-catalyzed asymmetric transfer hydrogenation of ketones (see Figure 5.4) ${ }^{26}$ High catalytic activities and enantioselectivities were obtained with ruthenium(II) complexes of ligands 5.4.b in the asymmetric hydrogenation of various aryl methyl ketones (ee of the 
alcohols $=67-98 \%$ for $\mathrm{R}=i \operatorname{Pr})$.<smiles>[R][C@H]1COC(c2cccc(-n3nc(C)cc3C)n2)=N1</smiles><smiles>[R]C1COC(c2cccc(-c3cc[nH]n3)n2)=N1</smiles>

Figure 5.4: Pyrazole-pyridine-oxazoline ligands

The same team also developed imidazole-pyridine-oxazolines (see Figure 5.5). Ruthenium(II) complexes of these ligands were used in the asymmetric transfer hydrogenation of aryl and alkyl methyl ketones, the NTs-bearing ligands yielding the most active and enantioselective catalysts (ee from 73 to $99.9 \%$ for $\mathrm{R}=i \mathrm{Pr}$ ). ${ }^{27,28}$

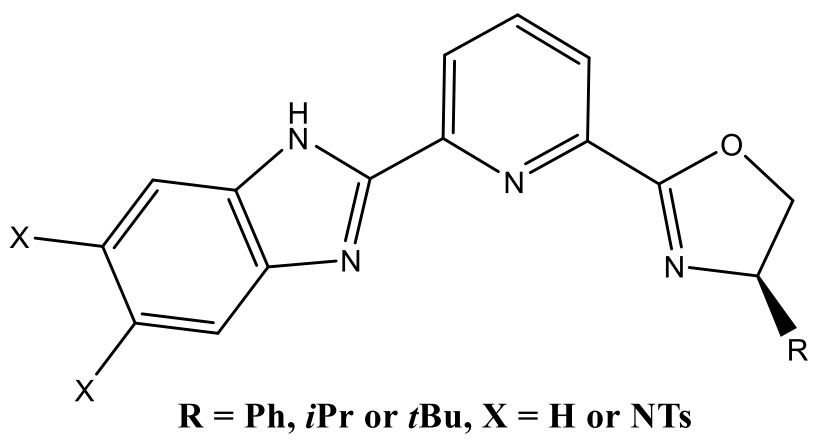

Figure 5.5: Benzimidazole-pyridine-oxazoline ligands.

Huang and coworkers developed in 2014 new imininopyridine-oxazolines (IPO, see Scheme 5.1). Their cobalt (II) complexes were used as catalysts in the first cobalt-catalyzed asymmetric hydroboration of alkenes with HBPin with complete regioselectivity and very good enantioselectivities, especially for 1-aryl-1'-alkyl-alkene and complex $\mathbf{5 . 5}$ (see Scheme 5.1). ${ }^{29}$ The same group used iron(II) complexes of IPO ligands for the asymmetric alkene hydrosilylation. Excellent results were obtained for aryl methyl ketones and a crowded IPO ligand $\left(\mathrm{R}=t \mathrm{Bu}, \mathrm{R}^{\prime}=\mathrm{CHPh}_{2}\right)$ : yields in the $63-99 \%$ range and ee in the $64 \%-93 \%$ range for 
almost all substrates. ${ }^{30}$ Huang et al. also used Mn(II) complexes of IPO ligands in the asymmetric alkene hydrosilylation, again with good results for aryl methyl ketones and the same crowded IPO ligand $\left(\mathrm{R}=t \mathrm{Bu}, \mathrm{R}^{\prime}=\mathrm{CHPh}_{2}\right): 68-99 \%$ yields and $79 \%-92 \%$ ee. ${ }^{31}$

Independently from Huang's group, Lu et al. synthesized IPO ligands via another synthetic pathway and used them in the iron-catalyzed asymmetric hydroboration (ee in the $87-92 \%$ range $)^{32}$ and hydrosilylation (ee in the $78-99 \%$ range $)^{33}$ of $1,1^{\prime}$-disubsituted alkenes.
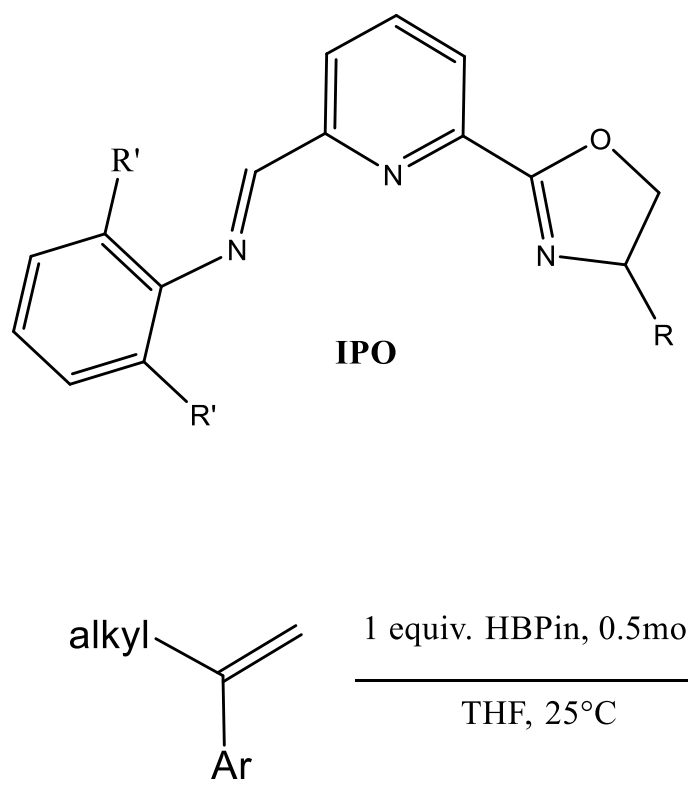

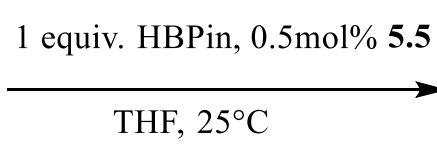

THF, $25^{\circ} \mathrm{C}$

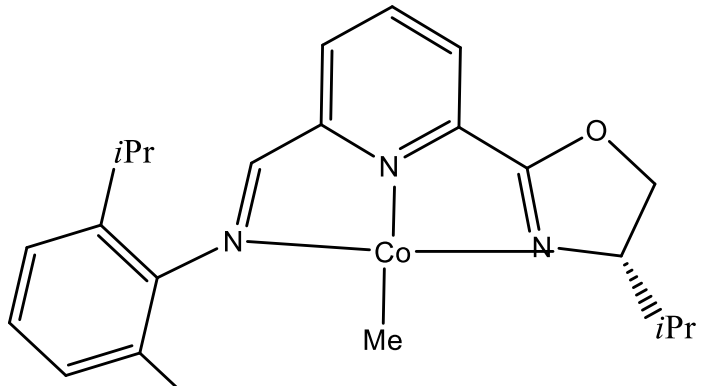

5.5

Scheme 5.1: Imininopyridine-oxazoline (IPO) ligands. Asymmetric hydroboration of 1,1 '-disubstituted alkene.

Lu et al. in addition to IPO ligands also developed oxazoline-aminoisopropylpyridines (OAP, see Figure 5.6). The $\mathrm{CoCl}_{2}(\mathrm{OAP})$ complexes proved to be efficient catalysts for the asymmetric hydroboration of 1-alkylstyrenes (yields in $35-81 \%$ range, ee in the $65-95 \%$ range with ligand with $\left.\mathrm{R}^{1}=2,6-(\mathrm{Me})_{2} \mathrm{C}_{5} \mathrm{H} 3, \mathrm{R}^{2}=t \mathrm{Bu}, \mathrm{R}^{3}=\mathrm{H}\right)$ with opposite product configuration to that obtained with the corresponding IPO. ${ }^{34}$ 


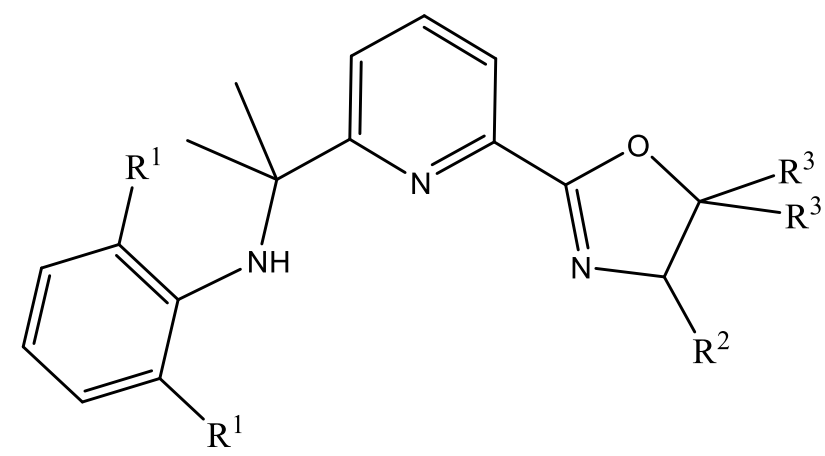

Figure 5.6: Oxazoline-aminoisopropylpyridine (OAP) ligands.

Zhang et al. described, to the best of our knowledge, the first analogue of pybox where the central pyridine was replaced by another nitrogen ligand (ambox, see Figure 5.7). Ruthenium(II) complexes of Ambox were used in the asymmetric transfer hydrogenation of aryl alkyl ketones. For most substrates, the reaction was complete with 1 mol\% of catalyst within 10 min with high enantioselectivities (ee in the 90-98\% range). ${ }^{35}$

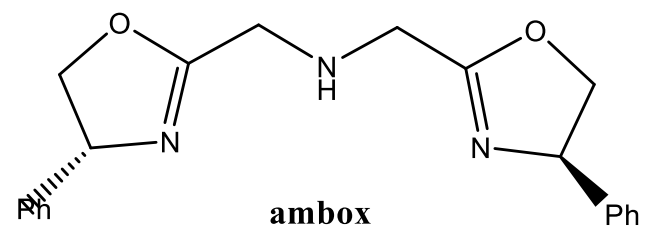

Figure 5.7: Ambox ligands

In 2002, Guiry and coworkers described a new pybox analogue with another linker between the two oxazoline groups: bis(oxazolynylphenyl)amine (Bopa, see Figure 5.8). Bopa are potential anionic N,N,N tridentate ligands after deprotonation. The authors used Bopa ligands in the acetophenone asymmetric transfer hydrogenation with good yields but low enantioselectivities (ee up to $18 \%$ ). ${ }^{36} \mathrm{Du}, \mathrm{Xu}$ and coworkers synthesized analogs of Bopa ligands with oxazoline rings replaced by thiazoline rings (Btpa, see Figure 5.8). They used both Bopa and Btpa in the Henry reaction of $\alpha$-ketoesters with nitromethane catalyzed by $\mathrm{Cu}(\mathrm{OTf})_{2} / \mathrm{NEt}_{3}$ with yields generally over $50 \%$ and moderate enatioselectivities (ee $=$ up to 
$82 \%$, similar for related Bopa and Btpa) ${ }^{37}$ but also in the Zn-catalyzed Henry reaction (with $\mathrm{ZnEt}_{2}$ ) with also good yields and enantioselectivities (ee in the 13-85\% range but with opposite product configuration to those obtained with the same ligands and the copper catalyst). ${ }^{38}$ Nishiyama et al. used Bopa ligands in the iron(II)-catalyzed asymmetric hydrosilylation of ketones with good yields and enantioselectivities (up to 95\% with bopa ligand with $\mathrm{R}=\mathrm{CHPh}_{2}, \mathrm{R}^{\prime}=\mathrm{H}, \mathrm{R}^{1}=\mathrm{R}^{2}=\mathrm{R}^{3}=\mathrm{H}$ ) which are highly dependent on the iron source $\left(\mathrm{Fe}(\mathrm{OAc})_{2}\right.$ or $\left.\mathrm{FeCl}_{3} / \mathrm{Zn}\right){ }^{39,40,41}$ Bopa ligand were also succesfully used in the cobalt-catalyzed asymmetric hydrosilylation of ketones (ee in the 38-98\% range with ligand with $\mathrm{R}=\mathrm{Ph}$, $\left.\mathrm{R}^{\prime}=\mathrm{H}, \mathrm{R}^{1}=\mathrm{R}^{2}=\mathrm{R}^{3}=\mathrm{H}\right) .^{40}$ Ward and coworkers used calcium ${ }^{42}$ and lanthanide $\mathrm{e}^{43}$ complexes of Bopa for the asymmetric intramolecular hydroamination: essentially full conversions were obtained with moderate enantioselectivities (ee up to $50 \%$ for $\mathrm{Ca}$ and up to $46 \%$ for lanthanides).

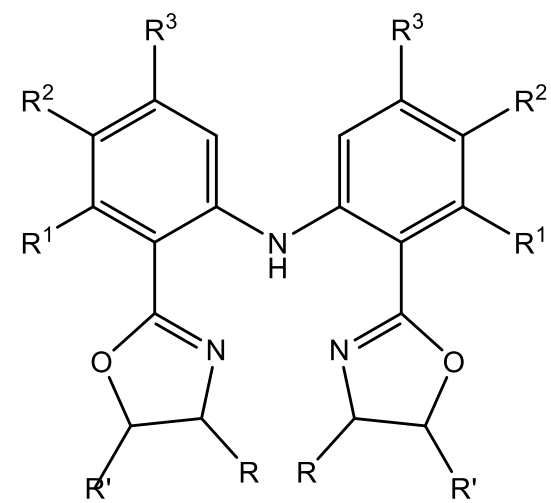

Bopa<smiles>[R]C1CSC(c2ccccc2Nc2ccccc2C2=NC([R])CS2)=N1</smiles>

Btpa

Figure 5.8: Bopa ligands and thiazoline analogs.

$\mathrm{Hu}$ and coworkers used Bopa Fe(III) complexes for the asymmetric cross-coupling reaction of alkyl halides with aryl Grignard reagents with low enantioselectivities (ee up to 19\%) (see Scheme 5.2, a)). ${ }^{44}$ Xiao et al. used Bopa zinc complexes for the synthesis of chromans by a tandem Friedel-Crafts/Michael addition reaction with moderate yields (54$80 \%$ range), very good diastereoselectivities (de over 90\%) and rather good 
enantioselectivies (ee in the 59-91\%). ${ }^{45}$ Recently, Rovis and coworkers used Zn(II) complexes of Bopa for the [4+2] cycloaddition of 1-azadienes and nitroalkenes. An optimization study of the Bopa ligand structure allowed the authors to identify a difluro-Bopa as the best ligand (see Scheme 5.2, b)). Under the optimized conditions, good yields (in the $43-87 \%$ range), high diasteroselectivies (de over 90\%) and enantioselectivities (up to 92\%) could be obtained. ${ }^{46}$ Zhang and coworkers used Bopa $\mathrm{Cu}(\mathrm{I})$ complexes for the enantioselective arylakynylation of alkenes ${ }^{47}$ and for the alkyne/ $\alpha$-bromoamide coupling $\left(\right.$ see Scheme 5.2, c)). ${ }^{48}$ 
a)<smiles>CCC(I)Cc1ccccc1</smiles>

$\underset{\mathrm{THF},-40^{\circ} \mathrm{C}, 15 \mathrm{~min}}{\stackrel{5 \mathrm{~mol} \% \text { complex }}{\longrightarrow}}$

$$
\begin{aligned}
& \text { 4- } \mathrm{MeOC}_{6} \mathrm{H}_{4} \\
& \text { yield }>95 \% \text {; } \\
& \text { ee }=19 \% \text { for } \mathrm{R}=t \mathrm{Bu}
\end{aligned}
$$

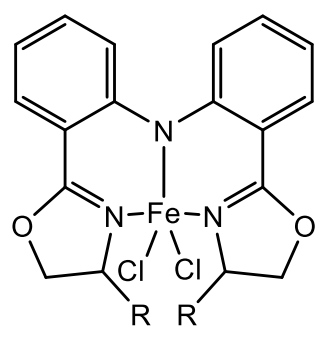

Iron complex

b)<smiles>O=[PH](O)/N=C\C=C\c1ccccc1</smiles><smiles>[R]C=C([R])[N+](=O)[O-]</smiles><smiles>[R]C1[C@H]([N+](=O)[O-])[C@@H](c2ccccc2)CC[C@H]1[R20]</smiles><smiles>O=C(OCc1ccccc1)[C@@H]1COC(c2c(F)cccc2Nc2cccc(F)c2C2=N[C@@H](C(=O)c3ccccc3)CO2)=N1</smiles>

optimized ligand:F-Bopa

c)

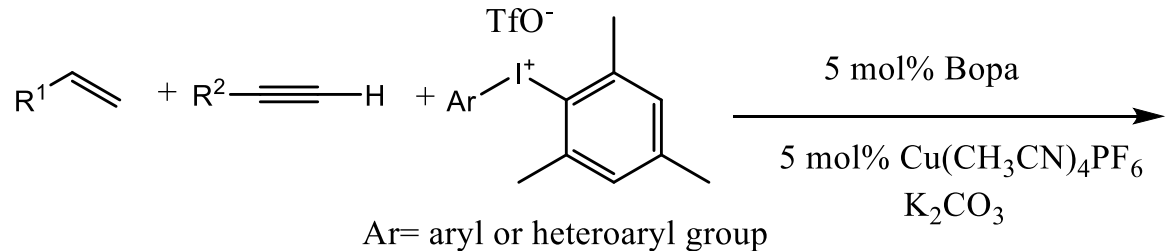<smiles>[R]C#CC([R])CBr</smiles>
yields up to $90 \%$ ee up to $98 \%$ with Bopa with $\mathrm{R}=t \mathrm{Bu}$<smiles>[R]C#C[CH-]</smiles><smiles>[R]C(Br)C(=O)N([R])[Al]</smiles>
$\mathrm{Ar}=$ 2,4,6-trimethylphenyl<smiles>[R]C#C[C@@H]([R2])C(=O)N([R])[Al]</smiles>

yields up to $82 \%$ ee up to $99 \%$ with Bopa with $\mathrm{R}=i \operatorname{Pr}$

Scheme 5.2: some asymmetric reactions with Bopa ligands.

Nakada et al. developed a Bopa ligand analogue with $o, o^{\prime}$-covalently bound phenyl 
rings, called carbazole bis(oxazolines) (Cbzbox, see Scheme 5.9) and used them in chromium-catalyzed Nozaki-Hiyama aldehyde allylation (ee up to $95 \%$ for $\mathrm{R}=i \operatorname{Pr}$ ), methallylation (ee up to $95 \%$ for $\mathrm{R}=i \mathrm{Pr})^{49,50}$ and propargylation (ee up to $98 \%$ for $\mathrm{R}=$ $t \mathrm{Bu}) .{ }^{51}$

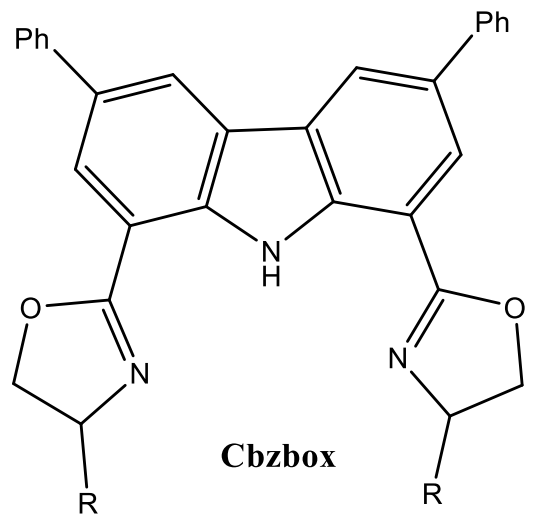

Figure 5.9: Cbzbox ligands.

Gade and coworkers described a new family of chiral potentially anionic N,N,N tridentate ligands after deprotonation: the bis(oxazolinylmethylidene)isoindolines (Boxmi, see Figure 5.10)..$^{52}$

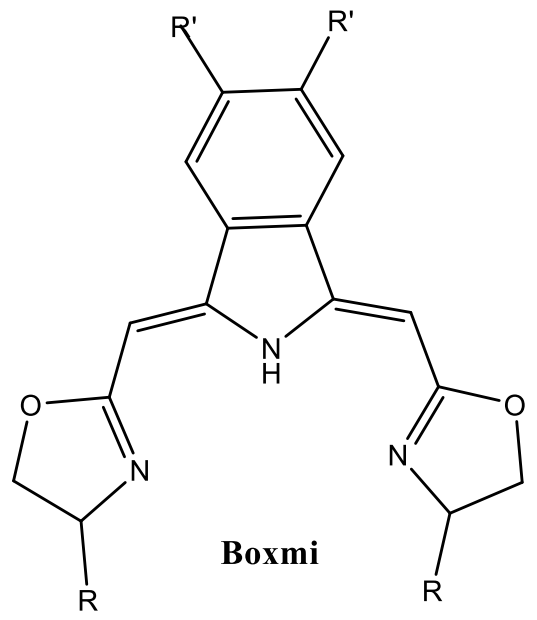

Figure 5.10: Boxmi.

Boxmi complexes were used in the enantioselective nickel-catalyzed oxindole fluorination (see Scheme 5.3, a)), ${ }^{52}$ chromium-catalyzed Nozaki-Hiyama-Kishi reaction (see 
Scheme 5.3, b)), ${ }^{52}$ and copper-catalyzed $\beta$-ketoester alkylation (see Scheme 5.3, c)). ${ }^{53}$ Boxmi copper complexes proved to be inefficient in the asymmetric oxindole alkylation, whereas the corresponding $\mathrm{Zn}$ complexes were highly successful (see Scheme 5.3, d)). ${ }^{54}$ The same zinc complexes were also used in the asymmetric oxindole cyanation with 4-acetylphenyl cyanate as cyanide source (see Scheme 5.3, e)). ${ }^{55}$ 
a)<smiles>[R]c1cccc2c1C([R1])C(=O)N2</smiles>

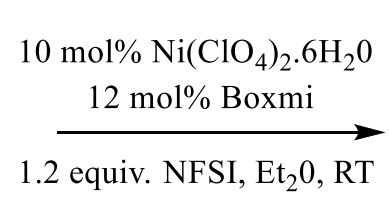<smiles>[R]c1cccc2c1[C@@]([R1])(F)C(=O)N2C(C)(C)C</smiles>

yields $=89-95 \% ;$ ee $=95->99 \%$ with $\mathrm{R}=\mathrm{Ph}, \mathrm{R}^{\prime}=\mathrm{H}$

b)<smiles>[R]C=O</smiles><smiles>[R3]C=C([R])CBr</smiles>

$10 \mathrm{~mol} \% \mathrm{Ni}\left(\mathrm{ClO}_{4}\right)_{2} \cdot 6 \mathrm{H}_{2} \mathrm{O}$ $12 \mathrm{~mol} \%$ Boxmi

1.2 equiv. NFSI, $\mathrm{Et}_{2} 0, \mathrm{RT}$<smiles>[R]C(=C)[C@@H]([R3])[C@@H]([R])O</smiles>

For $\mathrm{R}^{3}=\mathrm{H}$, yields $=90-94 \%$; ee $=75->90 \%$

For $\mathrm{R}^{3}=\mathrm{H}$, yields $=89-90 \%$; anti/syn $=3.7-10$, $\mathrm{ee}=86->93 \%$

with $\mathrm{R}=\mathrm{Ph}, \mathrm{R}^{\prime}=\mathrm{Me}$

c)<smiles>CCOC(=O)C1Cc2cc(OC)ccc2C1=O</smiles>

$+\quad \mathrm{R}^{1} \mathrm{OH}\left(\mathrm{R}^{1}\right.$ allylic or benzylic substituent)

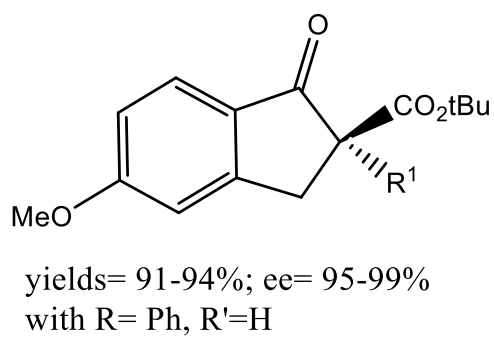

d)<smiles>[R]C1([R])C(=O)Nc2ccccc21</smiles>

$10 \mathrm{~mol} \% \mathrm{Zn}\left(\mathrm{NTf}_{2}\right)_{2}$<smiles>[R]OC([R])=[W]</smiles>

$+\quad \mathrm{R}^{1} \mathrm{Br}\left(\mathrm{R}^{1}\right.$ allylic or benzylic substituent)<smiles>[R]C1([R])C(=O)Nc2ccccc21</smiles>

yields $=84-90 \%$; ee $=94-98 \%$ with $\mathrm{R}=\mathrm{Ph}, \mathrm{R}^{\prime}=\mathrm{H}$

e)

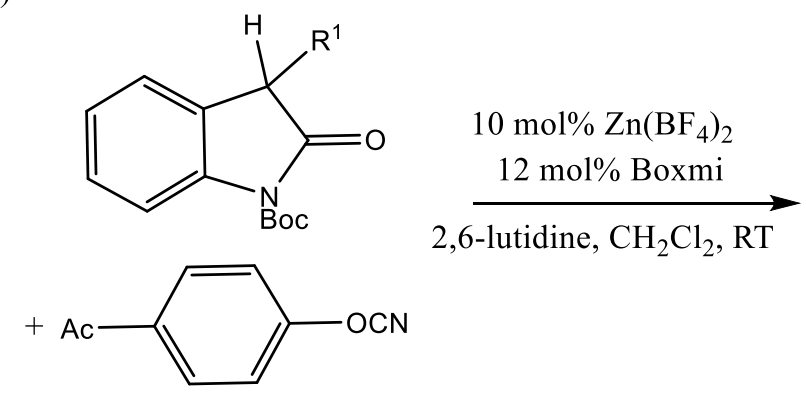<smiles>[R][C@]1(C#N)C(=O)Nc2ccccc21</smiles>

yields $=80-95 \%$; ee $=78-99 \%$ with $\mathrm{R}=\mathrm{Ph}, \mathrm{R}^{\prime}=\mathrm{H}$

Scheme 5.3: some asymmetric reactions with Boxmi ligands.

Boxmi iron(II) complexes were also applied to the ketone hydrosilylation, yielding 
alcohols in high yields and with high enantioselectivities for aryl alkyl ketones (yields = 95$99 \%$, ee $=94-99 \%$ with ligand with $\mathrm{R}=\mathrm{Ph}$ and $\left.\mathrm{R}^{\prime}=\mathrm{H}\right) .{ }^{56,57}$ The same iron complexes were also efficient in the hydroboration of functionalized ketones to yield halohydrines, oxaheterocycles or aminoalcohols ${ }^{58}$ and in the imine hydroboration to yield chiral amines in very good yields and with high enantioselectivities (ee in the 90-99\% range for most substrates with ligand with $\mathrm{R}=\mathrm{Ph}$ and $\left.\mathrm{R}^{\prime}=\mathrm{Me}\right) .{ }^{59}$ Boxmi manganese(II) complexes were also used in the ketone hydroboration providing alcohols in quantitative yields and high enantioselectivities for both aryl aryl and alkyl alkyl ketones (ee $=18-99 \%$ with ligand with $\mathrm{R}=\mathrm{Ph}$ and $\left.\mathrm{R}^{\prime}=\mathrm{H}\right){ }^{60,61}$ Cobalt(II) Boxmi complexes were also used in the asymmetric acetophenone hydrosilylation (ee up to $79 \%$ with ligand with $\mathrm{R}=\mathrm{Ph}$ and $\mathrm{R}$ ' $=\mathrm{H}$ ) ${ }^{62}$

\subsection{P,N,N ligands}

Clarke and coworkers developed, to the best of our knowledge, the first efficient P,N,N ligands $\mathbf{5 . 6}$ and $\mathbf{5 . 7}$ based on the 1,2-cyclohexane diamine scaffold (see Scheme 5.11). ${ }^{63,64,65}$ Ruthenium complexes of these ligands were used in the hydrogenation of a few phenyl alkyl ketones : with phenyl tert-butyl ketone good enantioselectivities could be achieved (ee up to $67 \%$ for $(\boldsymbol{S}, \boldsymbol{S}, \boldsymbol{S p})-\mathbf{5 . 7}$ and up to $85 \%$ for $\mathbf{5 . 6}$ with $\mathrm{X}=3,5$-di-t-butyl). The same team also developed 5.8 (analogue of 5.6) based on the $t$-stilbenediamine scaffold (see Scheme 5.11), which also proved to be efficient in the enantioselective ruthenium-catalyzed ketone hydrogenation (ee up to $80 \%$ in the hydrogenation of phenyl tert-butyl ketone). ${ }^{66}$ More recently, ligand 5.6 with $\mathrm{X}=\mathrm{H}$ was used in the iridium-catalyzed alkyl aryl ketone hydrogenation and transfer hydrogenation. ${ }^{67}$ Good enatioselectivities were, in particular, obtained when the alkyl group was 4-piperidyl (in the 75-96\% range) or cyclohexyl (up to $98 \%)$. 


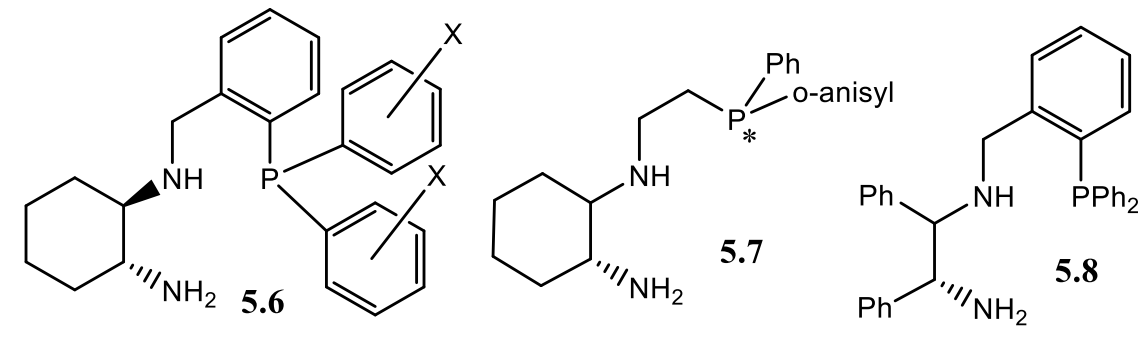

Figure 5.11: P,N,N ligands.

In 2011, Xie, Zhou and coworkers described a new spiro tridentate ligand family, called SpiroPAP (see Scheme 5.12). ${ }^{68}$ Iridium complexes of SpiroPAP were used in the asymmetric hydrogenation of various aryl alkyl and cycloalkyl alkyl ketones with very low loadings (typically $\mathrm{S} / \mathrm{C}=5000$ but the $\mathrm{S} / \mathrm{C}$ ratio could be decrease down to 5000000 in one case with a yield of $91 \%$ after 15 days ( $\mathrm{TON}=4550000)$ ) and very high enantioselectivities (products ee in the 88-99.9\% range for the ligand with $\mathrm{Ar}=3,5-(t \mathrm{Bu})_{2} \mathrm{C}_{6} \mathrm{H}_{3}$ and $\left.\mathrm{X}=3-\mathrm{Me}\right)$. This catalytic system was scaled up for the industrial asymmetric synthesis of rivastigmine, a drug for the treatment of Alzeimer's disease. ${ }^{69}$ The best route is presented in Scheme 5.4: the center of chirality was created in an asymmetric hydrogenation step using a SpiroPAP ligand with high yield (isolated yield $=94 \%$ at the 5 mmole scale) and enantioselectivity (ee $=$ 99.4\%). The same catalytic system was used in the asymmetric synthesis of a chiral intermediate in the synthesis of Montelukast, a leukotriene receptor antagonist, used for the treatment of asthma and seasonal allergies at the $30 \mathrm{~kg}$ scale $($ yield $=94 \%$, ee $=99.5 \%) .{ }^{70}$

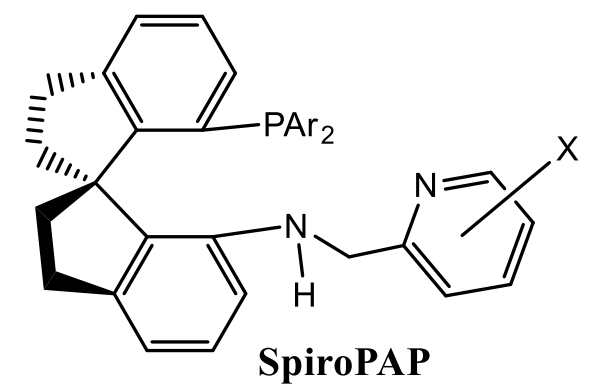

Figure 5.12: SpiroPAP ligands. 


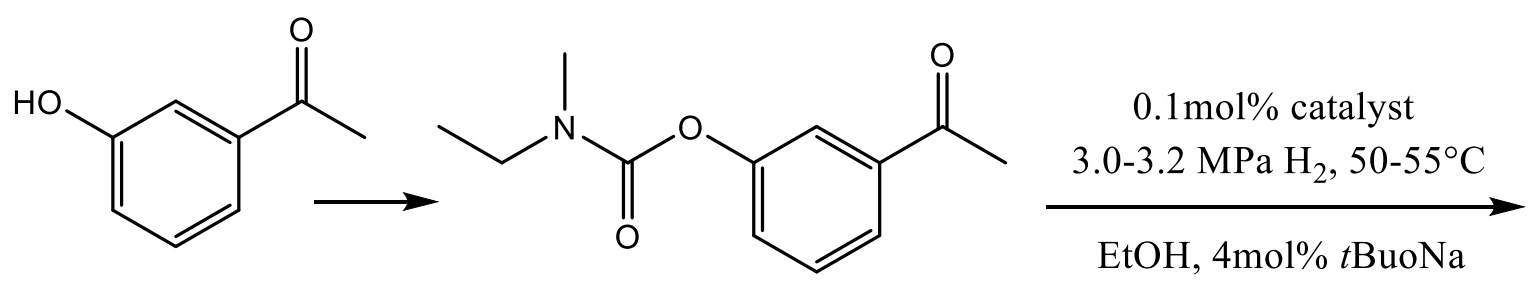

$1.1 \mathrm{~kg}(5 \mathrm{mmole})$

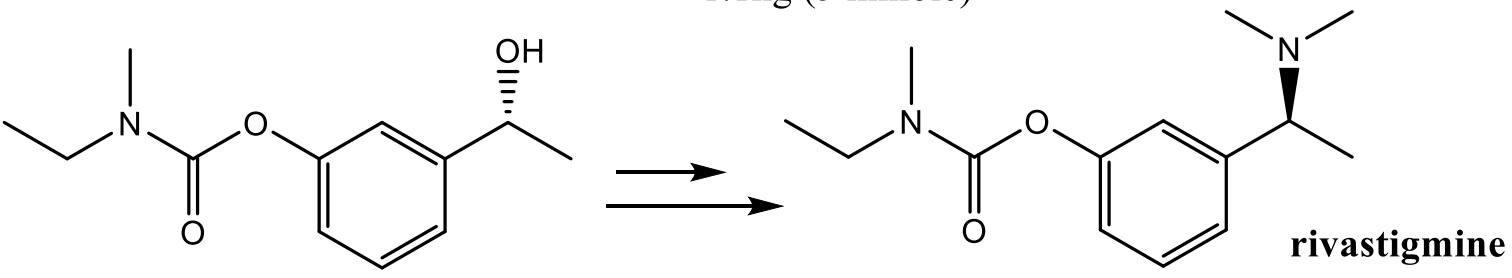

$1.04 \mathrm{~kg}(94 \%$ yield, $98.4 \%$ e.e. $)$

( $84 \%$ overall yield, $98.2 \%$ e.e.)

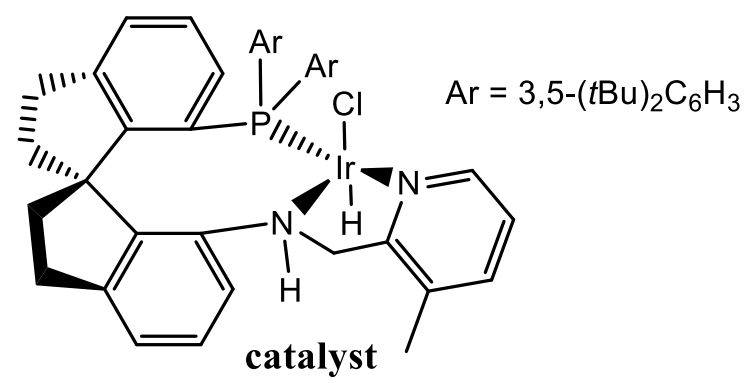

Scheme 5.4: asymmetric synthesis of Rivastigmine.

SpiroPAP iridium complexes were also used in the $\beta$-ketoester asymmetric hydrogenation with once again very high catalytic activities (typically $\mathrm{S} / \mathrm{C}=1000$ but a TON of 1230000 could be obtained using a S/C ration of 1500 000) and high enantioselectivities (product ee in the $88-95.8 \%$ range; $95-99.8 \%$ for $\beta$-aryl $\beta$-ketoesters) for the ligand with $\mathrm{Ar}=3,5$ $(t \mathrm{Bu})_{2} \mathrm{C}_{6} \mathrm{H}_{3}$ and $\mathrm{X}=3-\mathrm{Me}^{71}$ They were also used in the asymmetric hydrogenation of aryl and heteroaryl $\delta$-ketoesters (for $\mathrm{S} / \mathrm{C}=1000$, yield in the $92-97 \%$ range and ee in $96.7-99.9 \%$ range for the ligand with $\mathrm{Ar}=3,5-(t \mathrm{Bu})_{2} \mathrm{C}_{6} \mathrm{H}_{3}$ and $\left.\mathrm{X}=3-\mathrm{Me}\right)^{72}$ and in the asymmetric hydrogenation of alkyl and aryl $\alpha$-ketoacids (for $\mathrm{S} / \mathrm{C}=1000$, yield in the $92-98 \%$ range and ee in the 56-98\% range for the ligand with $\mathrm{Ar}=3,5-(t \mathrm{Bu})_{2} \mathrm{C}_{6} \mathrm{H}_{3}$ and $\left.\mathrm{X}=4-t \mathrm{Bu}\right) .{ }^{73}$ SpiroPAP iridium complexes were also used in the asymmetric hydrogenation of racemic $\alpha$-substituted lactones to yield chiral diols by dynamic kinetic resolution: the best results were again 
obtained with the ligand with $\mathrm{Ar}=3,5-(t \mathrm{Bu})_{2} \mathrm{C}_{6} \mathrm{H}_{3}$ and $\mathrm{X}=3-\mathrm{Me}$ (yields $=82-95 \%$, ee $=69-$ 95\%). ${ }^{74}$ The same SpiroAP iridium complexes were also efficient in the asymmetric transfer hydrogenation of ketones (for $\mathrm{S} / \mathrm{C}=1000$, yields $=90-99 \%$ range and ee $=80-98 \%$ range for ligand with $\mathrm{Ar}=3,5-(t \mathrm{Bu})_{2} \mathrm{C}_{6} \mathrm{H}_{3}$ and $\left.\mathrm{X}=\mathrm{H}\right) .{ }^{75}$

Recently, Yin, Zhang et al. developed a SpiroPAP analogue (O-SpiroPAP, see Scheme 5.5) and used it in the iridium-catalyzed hydrogenation of bridged biaryl lactones to axially chiral compounds with high yields and enantioselectivities (see Scheme 5.5). ${ }^{76}$
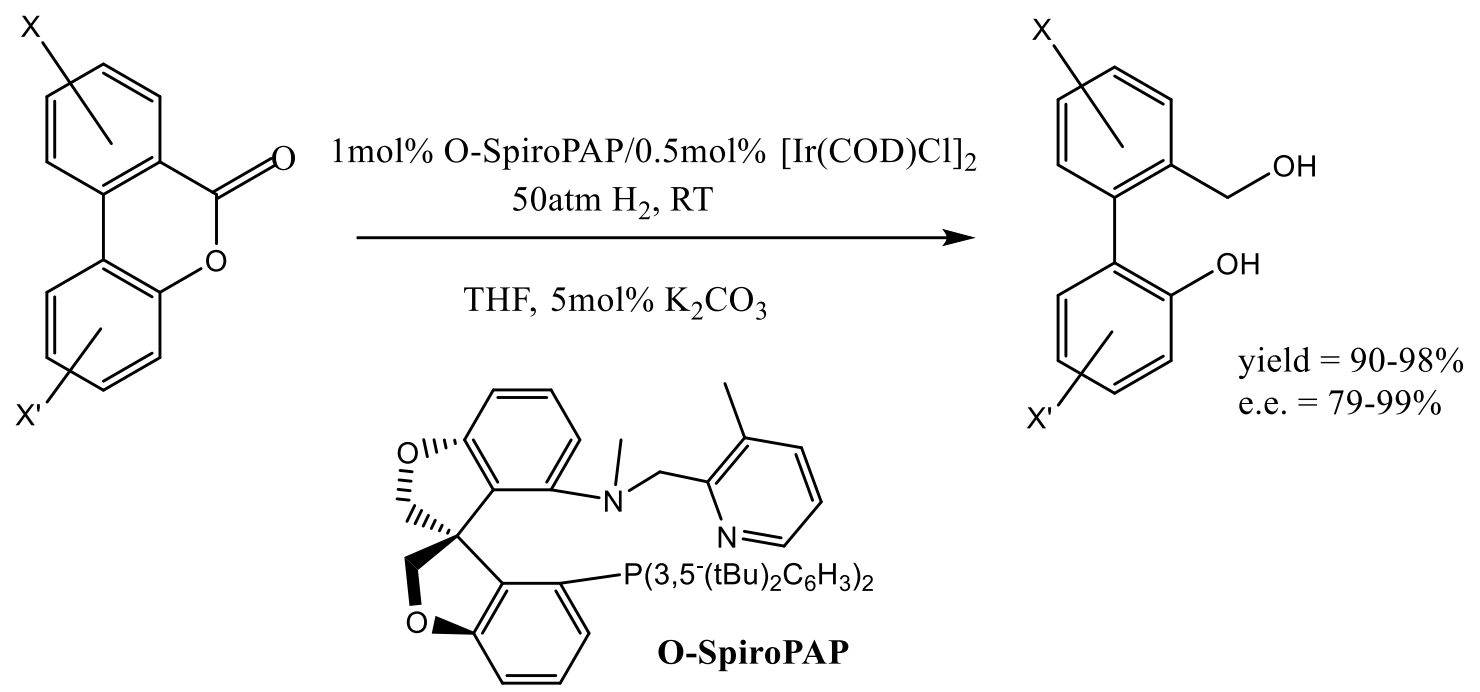

Scheme 5.5: 0-SpiroPAP.

Chen, Zhang and coworkers developed new ferrocene-based analogues of SpiroPAP 5.9 (see Figure 5.13) ${ }^{77}$ Ligands $\mathbf{5 . 9}$ were applied to the iridium-catalyzed asymmetric ketone hydrogenation: quantitative yields of alcohols were obtained with good enantioselectivities (for $\mathrm{S} / \mathrm{C}=2000$, ee $=60.8-86.6 \%$ for the ligand with $\mathrm{Ar}=3,5-(t \mathrm{Bu})_{2} \mathrm{C}_{6} \mathrm{H}_{3}$ and $\mathrm{X}=6-\mathrm{Me}$ ). Clarke and coworkers used the manganese complex $\mathbf{5 . 1 0}$ (see figure 5.14) in the hydrogenation of various aryl alkyl ketones to yield the corresponding alcohols in quantitative yields with ee in the $20-91 \%$ range (> $80 \%$ for crowded substrates) ${ }^{78}$ Recently, Zhong et al. synthesized ligands $\mathbf{5 . 1 1}$ (see Figure 5.13), a new family of analogues of ligands 
5.9 where the pyridine moiety is replaced by a benzimidazole group. ${ }^{79}$ These ligands were also used in the manganese-catalyzed asymmetric hydrogenation of ketones: for $\mathrm{S} / \mathrm{C}=1000$, yields were in the $95-99 \%$ range and ee in the $49.7-88.5 \%$ range for the ligand with $\mathrm{R}=\mathrm{Bz}$.
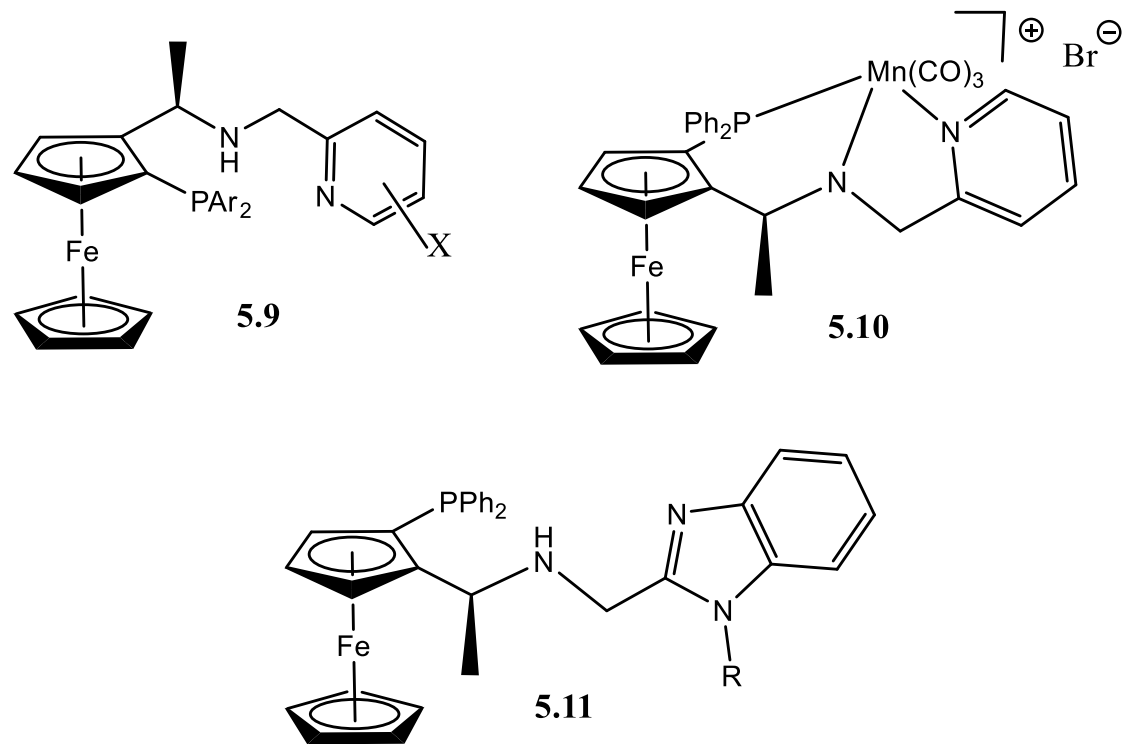

Figure 5.13 Ferrocene-based analogues of SpiroPAP ligands.

In 2012, Hu and coworkers used the chiral PNN ligands 5.12, previously synthesized in the same group, ${ }^{80}$ and also the similar ligand $\mathbf{5 . 1 3}$ (with $\mathrm{R}=\mathrm{H}$ ) in the copper-catalyzed asymmetric [3+3] cycloaddition of racemic propargylic esters with cyclic enamines (Scheme 5.6). The best selectivities were obtained with ligand 5.12, yielding less than $2 \%$ of alkylation byproduct 5.14 (yields $=58-88 \%$, endo/exo $>98 / 2$, ee $=67-98 \%$, see scheme 5.6 a) ${ }^{81}$ The authors proposed that a copper allenylidene complex is a key reaction intermediate and tested their catalytic systems against many different substrates. The same complexes were also used for the asymmetric copper-catalyzed [3+3] cycloaddition of racemic propargylic esters with 5-pyrazolones, resulting in high yields and very high enantioselectivities (ee $=71-97 \%$ for 5.12), ${ }^{82}$ as well as for the decarboxylative alkylation of propargyl $\beta$-ketoesters (ee $=83-98 \%$ for 5.13 with $\mathrm{R}=\mathrm{Ph}) .{ }^{83}$ The same group also exploited the ability of copper complexes of ligands $\mathbf{5 . 1 2}$ and $\mathbf{5 . 1 3}$ to activate propargylic esters to develop various asymmetric 
substitution reactions of racemic propargylic esters with different nucleophiles: nitrogen nucleophiles such as primary and secondary anilines (the best ligand being $\mathbf{5 . 1 2}$ for aromatic substrates with ee $=87-97 \%$ and $\mathbf{5 . 1 3}(\mathrm{R}=\mathrm{H})$ for aliphatic ones with ee $=78-95 \%$, see Scheme 5.6 b) ${ }^{84}$ oxygen nucleophiles such as oximes (ee $=77-92 \%$ with $\left.\mathbf{5 . 1 3}(\mathrm{R}=\mathrm{Ph})\right),{ }^{85}$ but also various carbon nucleophiles such as $\beta$-ketoesters $(e e=77-97 \% \text { with } \mathbf{5 . 1 3}(\mathrm{R}=\mathrm{Ph}))^{86}$ 1,3-dicarbonyl compounds (ee = 94-99\% with $5.13(\mathrm{R}=\mathrm{Ph})),{ }^{87}$ enamines $(\mathrm{ee}=96-98 \%$ with 5.12 for acyclic enamines ${ }^{88}$ and $80-97 \%$ with $\mathbf{5 . 1 3}(\mathrm{R}=\mathrm{Ph})$ for cyclic enamines), ${ }^{89}$ oxindoles (d.e. $>90 \%$, ee $=95-99 \%$ with $\mathbf{5 . 1 2}),{ }^{90}$ and coumarins $(e e=77-97 \%$ with $\mathbf{5 . 1 3}(\mathrm{R}=\mathrm{Ph})) .{ }^{91}$ With phenols as substrates, a Friedel-Crafts reaction, ${ }^{92}$ a [3+2] addition ${ }^{93}$ or even a dearomatization reaction ${ }^{94}$ could occur, always with high enantioselectivites (see Scheme 5.6 c)). 


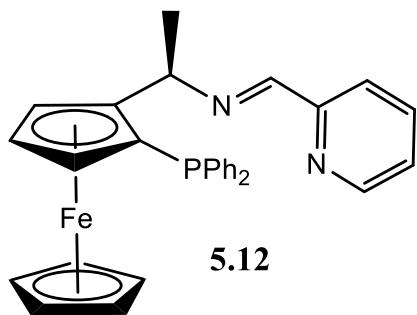<smiles>[R]C(=N[C@@H](C)c1ccccc1P)c1ccccn1</smiles>

$(R c, S p)$ (represented) or $(R c, S p)$

a)<smiles>[R]C(C#C)OC(C)=O</smiles>

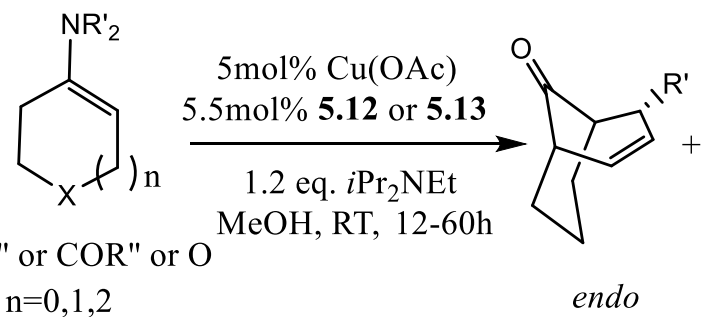<smiles>[R]C1C=CC2CCCC1C2=O</smiles>

exo<smiles></smiles>

5.14

b)<smiles>[R2]NC([R])C#C</smiles>

c)<smiles>[R]C(C#C)OC(C)=O</smiles>

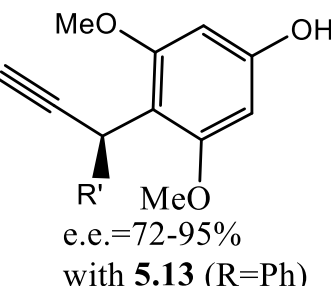<smiles>[R]C(C#CSC)OC([R])C(=O)OCC</smiles><smiles>[R]c1ccc2ccc3c(c2c1)[C@@H]([R4])C(=C)O3</smiles>

with $5.13\left(\mathrm{R}=3,5-\mathrm{C}_{6} \mathrm{H}_{3}\left(\mathrm{CF}_{3}\right)_{2}\right.$<smiles>[R20]Oc1cc(O)cc([R20])c1[R1]</smiles>

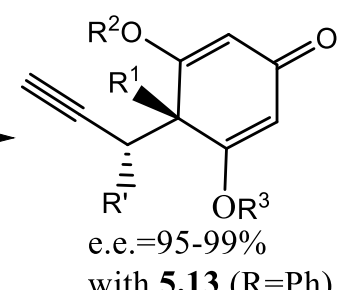

Scheme 5.6: New ligands developed by $\mathrm{Hu}$ and coworkers. 
Recently, Zhong and coworkers synthesized 5.15, the unsaturated analogue of $\mathbf{5 . 1 1}$ and an analogue of $\mathbf{5 . 1 2}$ with a benzimidazole group in place of the pyridine moiety (see Figure 5.14). ${ }^{95}$ Manganese complexes of this ligands were used in the asymmetric hydrogenation of unsymmetrical benzophenones, showing high catalytic activities (TON up to 13000 ) and high enantioselectivities (ee up to 99\%).

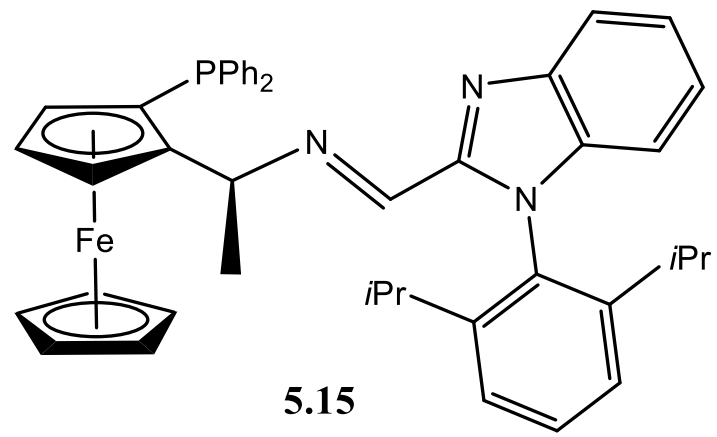

Figure 5.14: Ferrocene-based P,N,N ligand developed by Zhong and coworkers.

Lan, Dong, Zhang and coworkers developed new ferrocene-based P,N,N ligands bearing an oxazoline group (f-amphox, see Figure 5.15). ${ }^{96}$ These ligands were used in the iridium-catalyzed asymmetric hydrogenation of ketones: for $\mathrm{S} / \mathrm{C}=1000$, quantitative alcohol yields and ee in the 96-99.9\% range were obtained for the ligand with $\mathrm{Ar}=\mathrm{Ph}$ and $\mathrm{R}=t \mathrm{Bu}$. The same catalytic system was applied with low catalytic loadings (TON up to 1000 000) to the asymmetric hydrogenation of $\alpha$-hydroxy ketones $^{97}$ and $\alpha$-amino ketones ${ }^{98}$ to yield respectively 1,2-diols (ee $=98-99 \%)$ and 1,2-aminoalcohols $(\mathrm{ee}>99 \%)$ in quantitative yields. $\beta$-Ketoesters could also be efficiently hydrogenated in high yields (80-98\%) and enantioselctivies (71-95\%) using the same catalytic system, although higher catalyst loadings were necessary $(1 \mathrm{~mol} \%) .{ }^{99}$ 


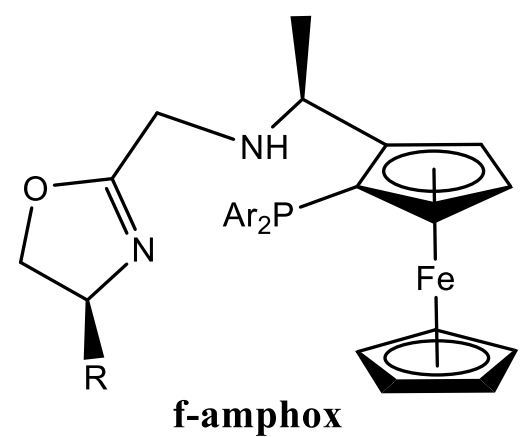

Figure 5.15: f-amphox ligands.

\section{$5.3 \mathrm{~N}, \mathrm{P}, \mathrm{N}$ ligands}

In 1997, Zhang and coworkers described the synthesis of 3 new chiral NPN ligands 5.16 $\left(\mathrm{R}^{1}=\mathrm{Ph}, \mathrm{R}^{2}=i \mathrm{Pr}, \mathrm{R}^{3}=\mathrm{H}\right)$ and $5.17\left(\mathrm{R}^{1}=\mathrm{Ph}, \mathrm{R}^{2}=\mathrm{H}, \mathrm{R}^{3}=\mathrm{Ph}\right.$ or $\mathrm{R}^{1}=\mathrm{Ph}, \mathrm{R}^{2}=i \mathrm{Pr}, \mathrm{R}^{3}=$ H) (see Scheme 5.7) and used them in the ruthenium-catalyzed transfer hydrogenation of ketones. ${ }^{100}$ The best results (ee in the $16-92 \%$ range) were obtained with $\mathbf{5 . 1 7}\left(\mathrm{R}^{1}=\mathrm{Ph}, \mathrm{R}^{2}=\right.$ $\left.\mathrm{H}, \mathrm{R}^{3}=\mathrm{Ph}\right)$.

Recently, Li and coworkers tested ligands $\mathbf{5 . 1 6}$ and $\mathbf{5 . 1 7}$ in the cobalt-catalyzed asymmetric allylic amination of racemic branched allylic carbonates (see Scheme 5.7 a)). ${ }^{101}$ Perfect regioselectivities and very high enantioselectivities were obtained, but the reaction was sluggish in certain cases. The best results (yield $=66-99 \%$, ee $=84-99 \%$ ) were obtained with $5.16\left(R^{1}=P h, R^{2}=P h, R^{3}=H\right)$. The same team extended the use of ligands $\mathbf{5 . 1 6}$ to the cobalt-catalyzed asymmetric allylic alkylation of carbon nucleophiles, in particular malonitriles (see Scheme 5.7 b)): good yields and very high enantioselectivities were obtained (yield = 61-96\%; ee = 90-99\% with $\left.5.16\left(R^{1}=M e, R^{2}=M e, R^{3}=O M e\right)\right) .{ }^{102}$ These ligands were also successfully used in the cobalt-catalyzed asymmetric allylic alkynylation of isatins (see Scheme 5.7 c)): yield = 71-96\%; ee = 92-99\% with $5.16\left(R^{1}=P h, R^{2}=M e, R^{3}=\right.$ 
H). ${ }^{103}$<smiles>[R][R]C1=NC(c2cc([R])ccc2P([R])c2ccc([R4])cc2C2=N[C@H]([R2])CO2)=N1</smiles>

5.16<smiles>[R]P(CCC1=NC([R])([R2])CO1)CCC1=NC([R2])([R2])CO1</smiles>

5.17

a)<smiles>[R]OC([R])C=C</smiles>

$$
+\left(\mathrm{R}^{\prime \prime}\right)\left(\mathrm{R}^{\prime \prime \prime}\right) \mathrm{NH} \underset{\mathrm{mol} \% \mathbf{5 . 1 6} \text { or } \mathbf{5 . 1 7}}{\stackrel{5 \mathrm{~mol} \% \mathrm{Cu}\left(\mathrm{BF}_{4}\right)_{2}}{5 \mathrm{~mol} \% \mathrm{Zn}}}
$$<smiles>[R]C([R])C=C</smiles>

$\mathrm{CH}_{3} \mathrm{CN}, \mathrm{RT}$

b)

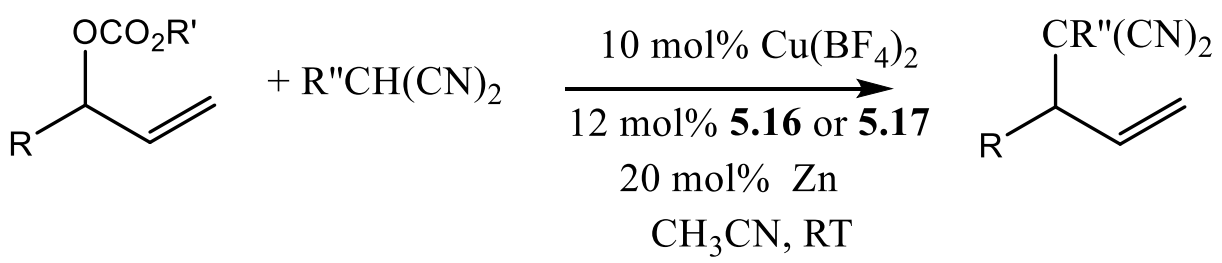

c)

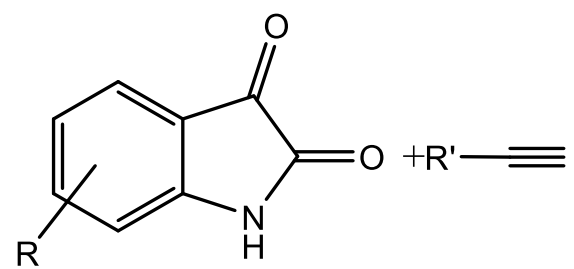
$\frac{5 \mathrm{~mol} \% \mathrm{Cu}(\mathrm{OAc})_{2}}{\underset{5 \mathrm{~mol} \% \mathbf{5 . 1 6} \text { or } \mathbf{5 . 1 7}}{\mathrm{EtOH}, 30^{\circ} \mathrm{C}}}$<smiles>[R]C#CC1(O)C(=O)Nc2ccccc21</smiles>

Scheme 5.7: Phosphine-bisoxazoline ligands.

\subsection{P,N,P ligands}

Morris and coworkers synthesized the chiral PNP ligands 5.18 (see Figure 5.16). ${ }^{104,105}$ The iron complexes $\left[\mathrm{FeBr}(\mathrm{CO})_{2}(\mathbf{5 . 1 8})\right]^{+}, \mathrm{BF}_{4}^{-}$after treatment with $\mathrm{LiAlH}_{4}$ followed by $t$ amylOH yield the monohydride complexes $[\mathrm{FeH}(\mathrm{O}-t$-amyl $)(\mathrm{CO})(\mathbf{5 . 1 9})]$, which are 
precatalysts in the asymmetric hydrogenation of ketones. After activation with a base $(\mathrm{KO} t \mathrm{Bu})$ under dihydrogen pressure, complexes $[\mathrm{FeH}(\mathrm{O}-t$-amyl $)(\mathrm{CO})(\mathbf{5 . 1 9})]$ yield the dihydride complexes $\left[\mathrm{FeH}_{2}(\mathrm{CO})(\mathbf{5 . 1 9})\right]$, which are proposed to be the active hydrogenation catalysts. ${ }^{106}$ Similar catalytic systems could also be obtained from $[\mathrm{FeH}(\mathrm{Cl})(\mathrm{CO})(\mathbf{5 . 1 9})]$ with a base $(\mathrm{KO} t \mathrm{Bu})$ under dihydrogen pressure. ${ }^{107}$ These catalytic systems proved to be very efficient (ee $=86-96 \%$ ) in the asymmetric hydrogenation of aryl alkyl ketones with low catalyst loadings (typically $0.1 \mathrm{~mol} \%$ ) and also in the asymmetric hydrogenation of activated imines (N-phosphinoyl and N-tosylimines) to yield the corresponding amines with high enantiomeric excesses (in the $90-98 \%$ range for most substrates). ${ }^{108}$
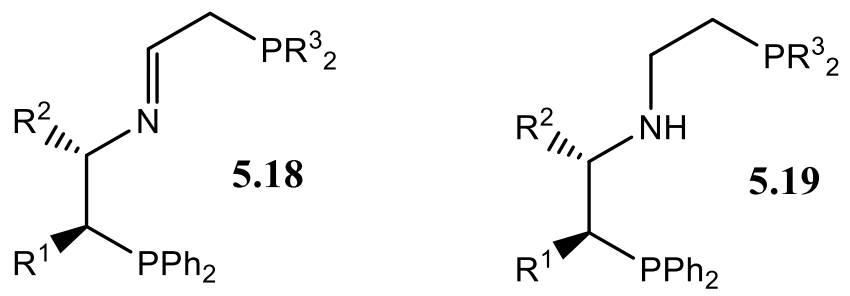

Figure 5.16: PNP ligands developed by Morris and coworkers.

Zirakzadeh and coworkers developed ferrocenyl ligands $\mathbf{5 . 2 0}$ (see figure 5.17), which were used in the iron-catalyzed hydrogenation of ketones: good to excellent alcohol yields could be obtained with ees up to $81 \% .^{109}$ The same ligands were also tested in the manganesecatalyzed transfer hydrogenation of ketones, yielding ees in the $20-85 \%$ range. ${ }^{110}$

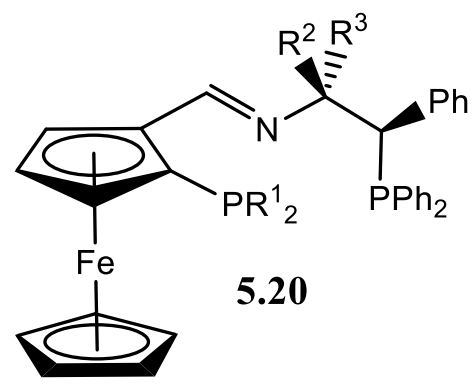

Figure 5.17: PNP ligands developed by Zirakzadeh and coworkers. 
Beller et al. synthesized a new chiral PNP 5.21 ligand bearing two stereogenic phospholane rings (see Figure 5.18). ${ }^{111}$ This ligand was tested in the asymmetric hydrogenation ok ketones with various metals $(\mathrm{Mn}, \mathrm{Re}, \mathrm{Fe}, \mathrm{Ru}):{ }^{112}$ the manganese and ironbased systems were especially efficient in the asymmetric hydrogenation of cyclic aliphatic ketones (ees up to $99 \%$ in both cases).

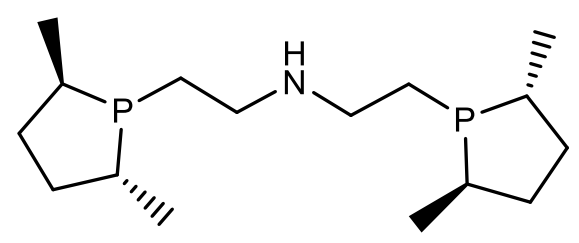

5.21

Figure 5.18: PNP ligand developed by Beller and coworkers.

\subsection{P,N,S ligands}

Recently, Xie, Zhou and coworkers developed PNS analogues (SpiroSAP) of the SpiroPAP ligands (see Figure 5.19). ${ }^{113}$ These ligands were used in the asymmetric iridiumcatalyzed hydrogenation of $\beta$-alkyl- $\beta$-ketoesters $($ yield $=91-98 \%$, ee $=95-99.9 \%$ with SpiroSAP(a)) and in the asymmetric iridium-catalyzed hydrogenation of racemic $\beta$ ketolactams by dynamic kinetic resolution (yield $=87-99 \%$, TON up to 5000, syn/anti from $97 / 3$ to $99 / 1$, ee $=83-99.9 \%$ with $\operatorname{SpiroSAP}(a)) .{ }^{114}$ 

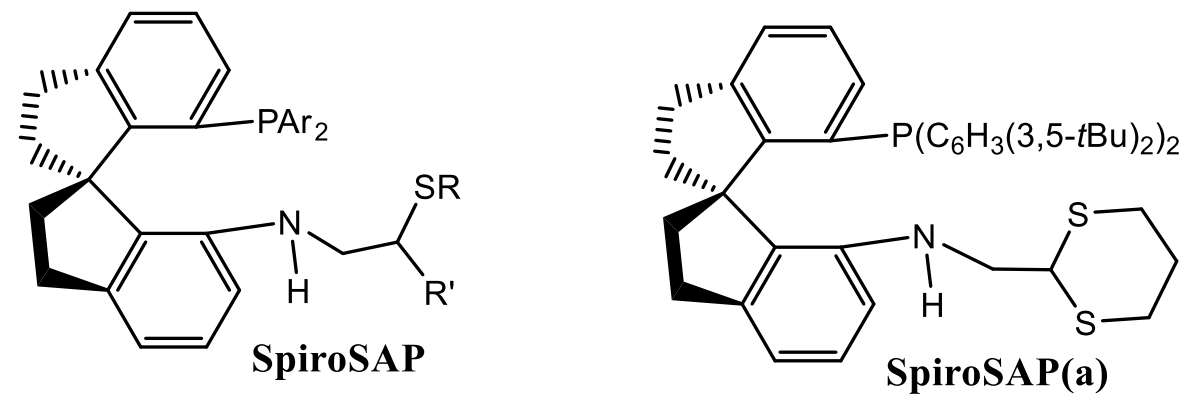

Figure 5.19: SpiroSAP ligands.

\subsection{N,N,O ligands}

Pseudodipeptide ligands

In 2002, Adolfsson and coworkers synthesized a new very modular family of NNO ligands 5.22, which were named pseudodipeptides, by coupling of $\mathrm{N}$-protected $\alpha$-aminoacids and various aminoalcohols (see Figure 5.20). ${ }^{115,116,117,118}$ These ligands were used in the ruthenium-catalyzed transfer hydrogenation of ketones with isopropanol under basic conditions. The screening of the different ligands led to the identification of two privileged structures 5.22a and 5.22b (see Figure 5.20). With these two ligands, very high enantioselectivities were obtained in the asymmetric transfer hydrogenation of aryl alkyl ketones (ee $=84-96 \%$ for $\mathbf{5 . 2 2 a}$; ee $=94-99 \%$ for $\mathbf{5 . 2 2} \mathbf{b}$ ). The addition of lithium salts was shown to increase the enantioselectivities when $i \mathrm{PrONa}$ or $i \mathrm{PrOK}$ were used as a base: a bimetallic outer-sphere type mechanism was then proposed. ${ }^{19,120}$ The same ligands were also employed in the rhodium-catalyzed transfer hydrogenation of ketones with isopropanol and

base. ${ }^{121}$ In this case, the best ligand was 5.22c (see Figure 5.20; ee $=61-98 \%$ for aryl or heteroaryl alkyl ketones). 


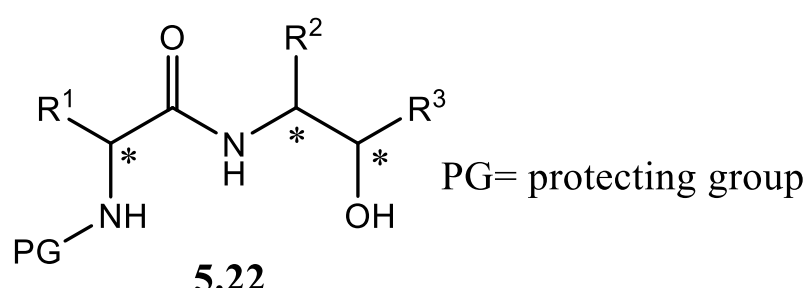<smiles>C[C@H](NC(=O)OCc1ccccc1)C(=O)N[C@@H](CO)c1ccccc1</smiles><smiles>CC(C)OC(=O)NC(C)C(=O)NC[C@@H](C)O</smiles><smiles>C[C@H](O)CNC(=O)C(NC(=O)OC(C)(C)C)C(=O)c1ccccc1</smiles>

Figure 5.20: Pseudodipeptide NNO ligands developed by Adolfsson and coworkers.

Adolfsson, Dieguez, Pamies and coworkers extended the pseudodipeptide NNO ligand family using carbohydrate-based aminoalcohols (see Figure 5.21). ${ }^{122,123,124}$ In particular, ligands $\mathbf{5 . 2 3}$ were identified as very efficient in the ruthenium-catalyzed transfer hydrogenation of ketones in isopropanol (ee $>99 \%$ for aryl alkyl ketones with 5.23; ee = 5199\% for aryl and heteroaryl alkyl ketones with 5.24).
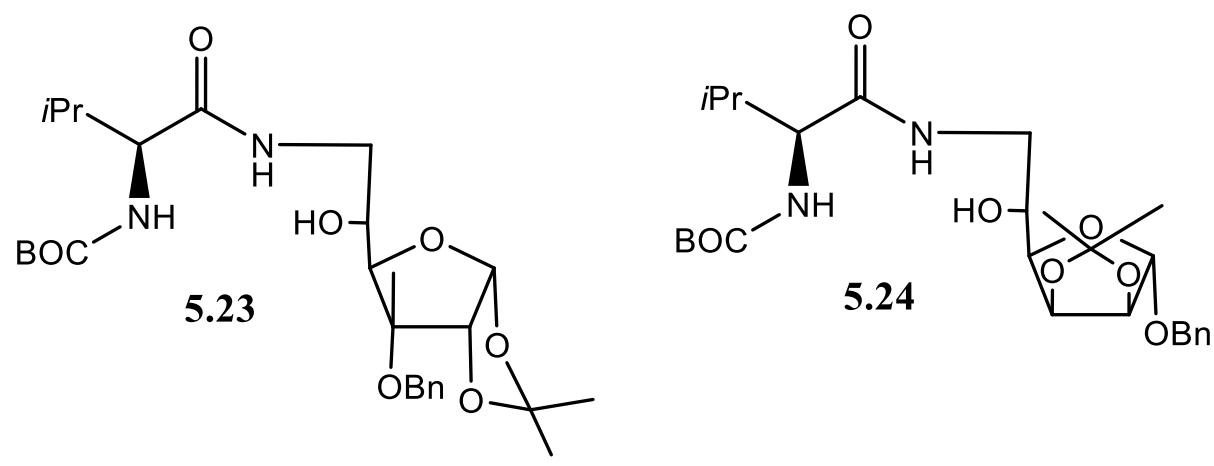

Figure 5.21: Carbohydrate-based pseudodipeptide NNO ligands developed by Dieguez, Pamies and Adolfsson. 


\section{Other NNO ligands}

Nishiyama and coworkers developed chiral atropoisomeric ligands BinThro (for Binolderived phenanThroline, see Figure 5.22) bearing a phenantroline and a phenol function and two stereogenic axes. ${ }^{125}$ These ligands were used in the asymmetric addition of $\mathrm{ZnEt}_{2}$ to aldehydes: yield $=32-94 \%$, ee $=59-95 \%$ when $\mathrm{Ar}=3,5-\left(\mathrm{F}_{3} \mathrm{C}\right)_{2} \mathrm{C}_{6} \mathrm{H}_{3}$ and $\mathrm{R}=\mathrm{H}$. These ligands were also tested in the asymmetric Michael addition to oxindoles: with 12 mol\% BinThro $(\mathrm{Ar}=\mathrm{Ph}, \mathrm{R}=\mathrm{Ph})$ and $10 \mathrm{~mol} \% \mathrm{Ni}(\mathrm{OAc})_{2}$, the yields were good in most cases (25$99 \%)$ and good enantioselectivities $(65-87 \%)$ were obtained with methyl vinyl ketone as Michael acceptor. ${ }^{126}$

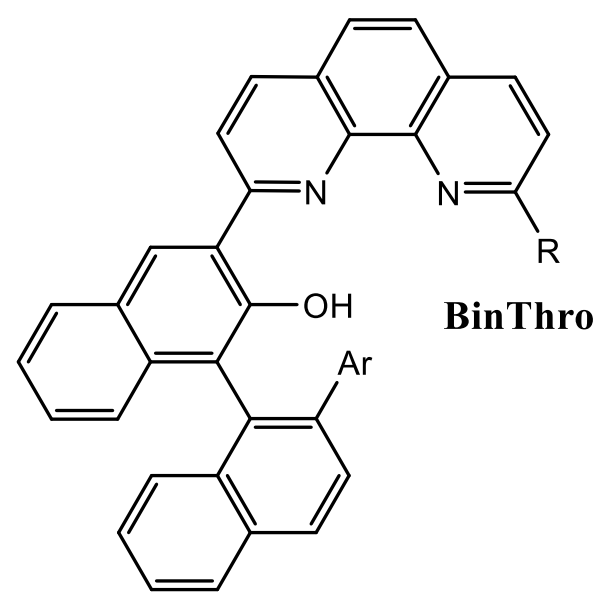

Figure 5.22: BinThro ligands developed by Nishiyama and coworkers.

BinThro ligands were also used in the copper-catalyzed asymmetric oxidations of oxindole ${ }^{127}$ and $\beta$-ketoesters (see Scheme 5.8). ${ }^{128}$ 
a)<smiles>[X]c1ccc2c(c1)C(Br)C(=O)N2C(=O)OCc1ccccc1</smiles>

b)<smiles>CC(=O)C1Cc2ccccc2C1=O</smiles>

$5 \mathrm{~mol} \% \mathrm{Cu}(\mathrm{OAc})_{2 .} \mathrm{H}_{2} \mathrm{O}$ $5.5 \mathrm{~mol} \%$ BinThro

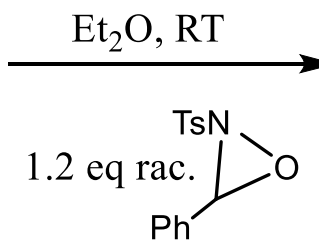<smiles>[X]c1ccc2c(c1)C(O)([Al])C(=O)N2C(C)(C)C</smiles>

yield $=71-93 \%$, ee $=67-96 \%$ with BinThro $(\mathrm{Ar}=3,5$-xylyl, $\mathrm{R}=\mathrm{H})$

1.2 eq rac. $5 \mathrm{~mol} \% \mathrm{Cu}(\mathrm{OAc})_{2 .} \mathrm{H}_{2} \mathrm{O}$ $5.5 \mathrm{~mol} \%$ BinThro<smiles>C=C1c2ccccc2CC1(O)C(=O)OCC</smiles>

c)<smiles>CC(=O)C1Cc2ccccc2C1=O</smiles>

$$
5 \mathrm{~mol} \% \mathrm{Cu}(\mathrm{TFA})_{2}
$$

$$
6 \text { mol\% BinThro }
$$

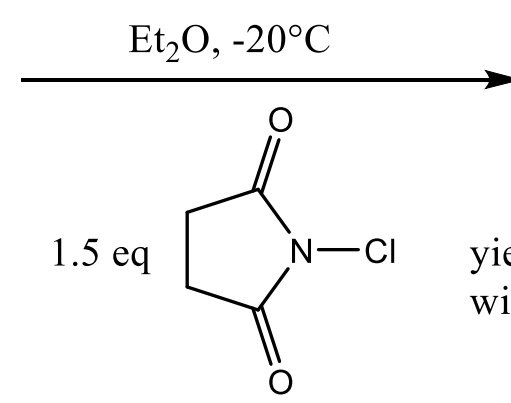<smiles>CC(=O)C1(O)Cc2ccccc2C1=O</smiles>

yield $=89-99 \%$, ee $=83-93 \%$ with BinThro $(\mathrm{Ar}=3,5$-xylyl, $\mathrm{R}=\mathrm{H})$

Scheme 5.8: Oxidation reactions with BinThro ligands.

\subsection{O,N,O ligands}

By condensation of salicylaldehydes with 1,2-aminoalcohols, various chiral ONO ligands 5.25 have been synthesized (see Scheme 5.9) and used in various asymmetric reactions such as the Henry reaction (see Scheme 5.9 a), ${ }^{129,130,131}$ the vanadium oxidation of 
thioethers to sulfoxides (ees up to $94 \%$ with $\mathbf{5 . 2 5}\left(\mathrm{R}^{1}=\mathrm{Ph} ; \mathrm{R}^{2}=\mathrm{R}^{3}=\mathrm{R}^{4}=\mathrm{R}^{5}=\mathrm{H}, \mathrm{R}^{6}=\right.$ OMe), ${ }^{132,133,134,135}$ the copper-catalyzed Friedel-Crafts reaction of pyrroles on nitroalkenes (ee =90-98\% with $5.25\left(\mathrm{R}^{1}=p\right.$-tolyl; $\left.\mathrm{R}^{2}=\mathrm{R}^{3}=\mathrm{R}^{4}=\mathrm{R}^{6}=\mathrm{H}, \mathrm{R}^{5}=\mathrm{CF}_{3}\right),{ }^{136}$ or the aluminiumcatalyzed (ee $=95-99 \%$ with $\mathbf{5 . 2 5}\left(\mathrm{R}^{1}=\right.$ isobutyl; $\mathrm{R}^{2}=\mathrm{R}^{3}=\mathrm{R}^{4}=\mathrm{H}, \mathrm{R}^{5}=$ adamantyl, $\mathrm{R}^{6}=$ $t \mathrm{Bu}$ ) or iron-catalyzed (ee $=83-95 \%$ with a camphor-based ligand) hydrophosphonylation of aldehydes. ${ }^{137,138}$

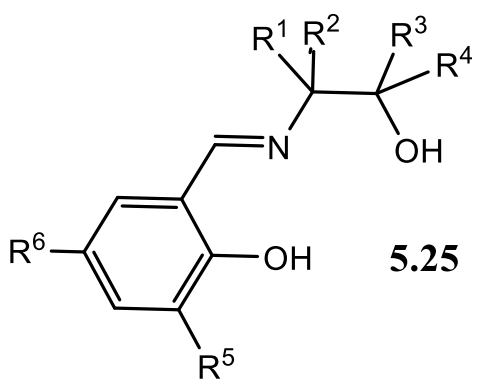

a)<smiles>[X]c1ccc(C=O)cc1</smiles>

b)

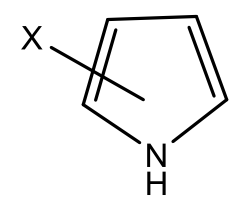

$$
\begin{aligned}
& 10 \mathrm{~mol} \% \mathrm{Cu}(\mathrm{OAc})_{2} \cdot \mathrm{H}_{2} \mathrm{O} \\
& 10 \mathrm{~mol} \% \mathbf{5 . 2 5} \\
& \underset{\mathrm{CH}_{3} \mathrm{NO}_{2}}{\stackrel{\mathrm{Et}_{2} \mathrm{O}, \mathrm{RT}}{\longrightarrow}}
\end{aligned}
$$

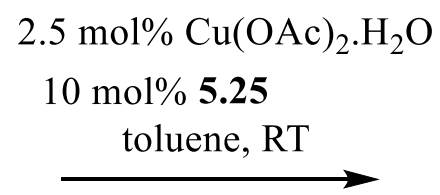<smiles>[R]C=C[N+](=O)[O-]</smiles>

$$
\begin{aligned}
& \text { yield }=72-98 \%, \text { ee }=90-98 \% \\
& \text { with } 5.25\left(R^{1}=B n ; R^{2}=H ;\right. \\
& \left.R^{3}=R^{4}=\text { - } \text {-tolyl; } R^{5}=C F_{3} ; R^{6}=H\right)
\end{aligned}
$$

Scheme 5.9: ONO ligands from salicylaldehyde. 


\section{$5.8 \mathrm{~N}, \mathrm{C}, \mathrm{N}$ ligands}

Designed as an anionic analogue (after deprotonation) of Pybox, Phebox was originally developed independently by three different teams (see Scheme 5.10). ${ }^{139,140,141}$ This family of ligands has been successfully used in various asymmetric reactions such as alkene hydrosilylation, the aldol reaction, the reductive aldol reaction, or the $\beta$-boration of $\alpha, \beta$ unsaturated esters. ${ }^{142,143,144}$ Phebox continues to attract interest for the development of new catalytic systems, for instance for ruthenium-catalyzed asymmetric three-component coupling reaction of alkyne, enone and aldehyde (see Scheme $5.10 \mathrm{a}),{ }^{145}$ or the rhodium-catalyzed asymmetric alkynylation of $\alpha$-ketiminoesters see Scheme 5.10b). ${ }^{146,147}$ 


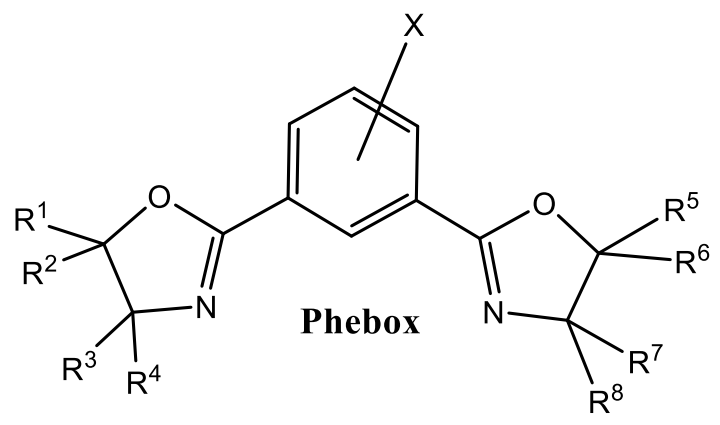

a)

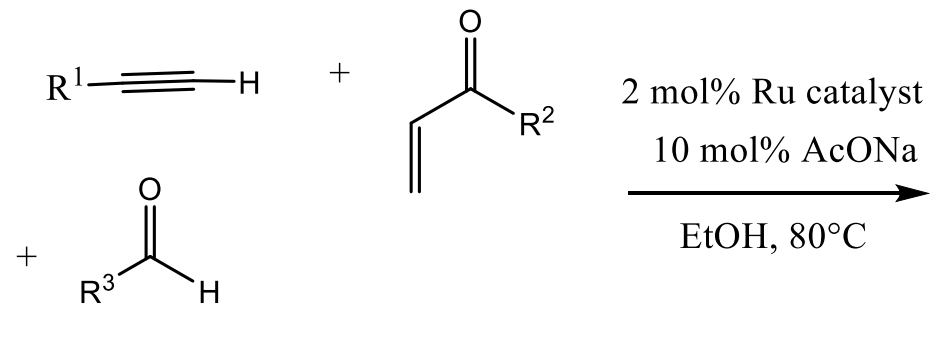

yield $=38-86 \%$, anti/syn up to 3 ; ee $($ anti $)=90-97 \%$ with<smiles>[R]C(=O)C(CC#CI)C([R])O</smiles>

b)<smiles>[R]C#C[R17]OC(=O)/C(=N/[R6])C(F)(F)F</smiles>

$0.5 \mathrm{~mol} \% \mathrm{Rh}$ catalyst toluene, RT<smiles>[R]C#C[C@](C)(CCC)NC(=O)OCc1ccccc1</smiles>

yield $=84-98 \% ;$ ee $=80-95 \%$ with

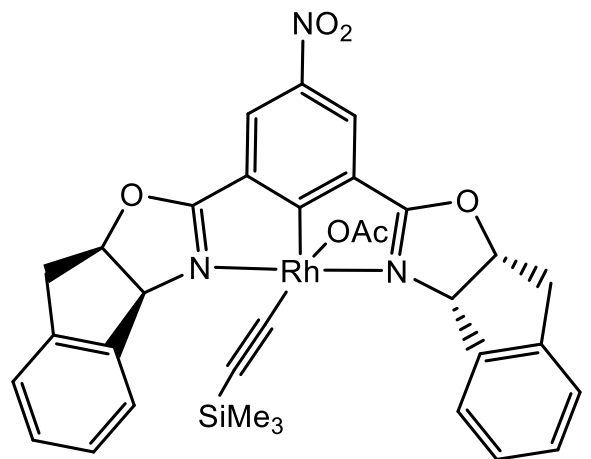

Scheme 5.10: Phebox ligands

In 2006, Gong, Song and coworkers described a new very modular family of analogues of the Phebox ligands called Phebim where oxazoline rings have been replaced by imidazoline rings (see Figure 5.23). ${ }^{148}$ Phebim ligands were used in the platinum-catalyzed 
alkylation of indoles with nitroalkenes (yield $=61-99 \%$, ee $=34-83 \%$ for the ligand with $\mathrm{R}^{1}=$ $\left.i \operatorname{Pr}, \mathrm{R}^{2}=\mathrm{R}^{3}=\mathrm{R}^{4}=\mathrm{R}^{6}=\mathrm{H}, \mathrm{R}^{5}=\mathrm{Cy}\right),{ }^{149,150}$ in the palladium-catalyzed aza-Morita-BaylisHillman reaction of acrylonitrile with imines (yield $=75-98 \%$, ee $=76-98 \%$ for the ligand with $\mathrm{R}^{1}=\mathrm{R}^{3}=1$-naphtyl, $\left.\mathrm{R}^{2}=\mathrm{R}^{4}=\mathrm{R}^{6}=\mathrm{H}, \mathrm{R}^{5}=\mathrm{Ac}\right),{ }^{151}$ in the rhodium-catalyzed allylation of aldehydes with allyltributyltin (yield $=78-99 \%$, ee $=37-97 \%$ for the ligand with $\mathrm{R}^{1}=\mathrm{Bn}$, $\mathrm{R}^{2}=\mathrm{R}^{3}=\mathrm{R}^{4}=\mathrm{R}^{6}=\mathrm{H}, \mathrm{R}^{5}=p$-tolyl), ${ }^{152}$ in the rhodium-catalyzed carbonyl-ene of ethyl trifluoropyruvates with 2-arylpropene (yield $=60-89 \%$, ee $=65-94 \%$ for the ligand with $\mathrm{R}^{1}=$ $t \mathrm{Bu}, \mathrm{R}^{2}=\mathrm{R}^{3}=\mathrm{R}^{4}=\mathrm{R}^{6}=\mathrm{H}, \mathrm{R}^{5}=p$-tolyl $),{ }^{152}$ in the rhodium-catalyzed alkynylation of ethyl trifluoropyruvates (with aromatic terminal alkynes: yield $=80-99 \%$, ee $=94-99 \%$ for the ligand with $\mathrm{R}^{1}=\mathrm{R}^{3}=\mathrm{Ph}, \mathrm{R}^{2}=\mathrm{R}^{4}=\mathrm{H}, \mathrm{R}^{5}=p$-tolyl, $\mathrm{R}^{6}=\mathrm{NO}_{2}$; with aliphatic terminal alkynes: yield $=68-86 \%$, ee $=52-99 \%$ for the ligand with $\mathrm{R}^{1}=\mathrm{R}^{3}=\mathrm{Ph}, \mathrm{R}^{2}=\mathrm{R}^{4}=\mathrm{H}, \mathrm{R}^{5}=p$ tolyl, $\left.\mathrm{R}^{6}=\mathrm{NO}_{2}\right),{ }^{153}$ in the palladium-catalyzed hydrophosphination of enones with diphenylphosphine (yield $=20-90 \%$, ee $=79-94 \%$ for the ligand with $\mathrm{R}^{1}=\mathrm{R}^{3}=\mathrm{Ph}, \mathrm{R}^{2}=\mathrm{R}^{4}=$ $\mathrm{R}^{6}=\mathrm{H}, \mathrm{R}^{5}=p$-tolyl $)^{154}$ and in the iridium-catalyzed $\mathrm{C}-\mathrm{H}$ functionalization of indoles with $\alpha$ aryl- $\alpha$-diazoacetates (yield $=21-99 \%$, ee $=6-86 \%$ for the ligand with $\mathrm{R}^{1}=\mathrm{R}^{3}=\mathrm{Ph}, \mathrm{R}^{2}=\mathrm{R}^{4}=$ $\mathrm{H}, \mathrm{R}^{5}=p$-tolyl, $\left.\mathrm{R}^{6}=t \mathrm{Bu}\right) .{ }^{155}$<smiles>[R7]c1cc(C2=NC([R])([R])C([R])([R])N2[R])cc(C2=NC([R])([R])C([R])([R])N2[R7])c1</smiles>

Figure 5.19: Phebim ligands. 


\subsection{Conclusion}

A very large variety of asymmetric catalytic systems has already been developed using numerous chiral tridentate ligands of various shapes and coordination patterns for a very large panel of chemical reactions. Chiral tridentate ligands are now well established tools for synthetic chemists and for catalyst developer and should continue to raise great interest in the next decades.

\footnotetext{
${ }^{1}$ Desimoni, G., Faita, G., Quadrelli, P., Chem. Rev. 2003, 103, 3119-3154.

${ }^{2}$ Babu, S. A., Khrisnan, K. K., Ujwaldev, S. M., Anilkumar, G., Asian J. Org. Chem. 2018, 7, 1033-1053.

${ }^{3}$ Rohit, K. R., Ujwaldev, S. M., Saranya, S., Anilkumar, G., Asian J. Org. Chem. 2018, 7, 2338-2356.

${ }^{4}$ Nishiyama, H., Sakaguchi, H., Nakamura, T., Horihata, M., Kondo, M., Itoh, K., Organometallics 1989, 8, 846-846.

${ }^{5}$ Johnson, J. S., Evans, D. A., Acc. Chem. Res. 2000, 33, 325-335.

${ }^{6}$ Nishiyama, H., Kondo, M., Nakamura, T., Horihata, M., Itoh, K., Organometallics 1991, 10, 500-508.

${ }^{7}$ Uvarov, V. M., de Vekki, D. A., J. Organomet. Chem. 2020, 923, 121415.

${ }^{8}$ Nishiyama, H., Enantiomer 1999, 4, 569-574.

${ }^{9}$ Sekar, G., Datta Gupta, A., Singh, V. K., J. Org. Chem. 1998, 63, 2961-2967.

${ }^{10}$ Singh, P. K., Singh, V. K., Pure Appl. Chem. 2012, 84, 1651-1657

${ }^{11}$ Wang, H., Wang, H., Liu, P., Yang, H., Xiao, J., Li, C., J. Mol. Catal. A Chem. 2008, 285, 128-131.

12 Sibi, M. P., Cruz, W. Jr, Stanley, L. M., Synlett 2010, 6, 889-892.

${ }^{13}$ Zhao, B, Loh, T.-P., Org. Lett. 2013, 15, 2914-2917.

${ }^{14}$ Wang, Z., Bachman, S., Dudnik, A. S., Fu, G. C., Angew. Chem. Int. Ed. 2018, 57, 14529-14532.

${ }^{15}$ Garcia, K. J., Gilbert, M. M., Weix, D. J., J. Am. Chem. Soc. 2019, 141, 1822-1827.

${ }^{16}$ Wang, C., Zhu, R.-Y., Liao, K., Zhou, F., Zhou, J., Org. Lett. 2019, 22, 1270-1274.

${ }^{17}$ Zhu, Q., Meng, B., Gu, C., Xu, Y., Chen, J., Lei, C., Wu, X., Org. Lett. 2019, 21, 9985-9989.
} 
${ }^{18}$ Calvo, R., Comas-Vives, A., Togni, A., Katayev, D., Angew. Chem. Int. Ed. 2019, 58, 1447-1452.

${ }^{19}$ Das, B. G., Shah, S., Singh, V. K., Org. Lett. 2019, 21, 4981-4985.

${ }^{20}$ Cobo, A. A., Armstrong, B. M., Fettinger, J. C., Franz, A. K., Org. Lett. 2019, 21, 8196-8200.

${ }^{21}$ Liu, E.-C., Topczewski, J. J., J. Am. Chem. Soc. 2019, 141, 5135-5138.

${ }^{22}$ Li, L., Han, F., Nie, X., Hong, Y., Ivlev, S., Meggers, E., Angew. Chem. Int. Ed. 2020, 59, 12392-12395.

${ }^{23}$ Anilkumar, G., Bhor, S., Tse, M. K., Klawonn, M., Bitterlich, B., Beller, M., Tetrahedron: Asymmetry. 2005, $16,3536-3561$.

${ }^{24}$ Junge, K., Möller, K., Wendt, B., Das, S., Gördes, D., Thurow, L., Beller, M., Chem. Asian J. 2012, 7, $314-$ 320.

${ }^{25}$ Monge, D., Bermejo, A., Vasquez, J., Fernandez, R., Lassaletta, J. M., Arkivoc 2013, 33-45.

${ }^{26}$ Ye, W., Zhao, M., Yu, Z., Chem. Eur. J. 2012, 18, 10843-10846.

${ }^{27}$ Ye, W. J., Zhao, M., Du, W. M., Jiang, Q., Wu, K., Wu, P., Yu, Z., Chem. Eur. J. 2011, 17, 4737-4741.

${ }^{28}$ Chai, H., Liu, T., Yu, Z., Organometallics 2017, 36, 4136-4144.

${ }^{29}$ Zhang, L., Zuo, Z., Wan, X., Huang, Z., J. Am. Chem. Soc. 2014, 136, 15501-15504.

${ }^{30}$ Zuo, Z., Zhang, L., Leng, X., Huang, Z., Chem. Commun. 2015, 51, 5075-5076.

${ }^{31}$ Ma, X., Zuo, Z., Liu, G., Huang, Z., ACS Omega 2017, 2, 4688-4692.

${ }^{32}$ Chen, J., Xi, T., Lu, Z., Org. Lett. 2014, 16, 6452-6455.

${ }^{33}$ Chen, J., Cheng, B., Cao, M., Lu, Z., Angew. Chem. Int. Ed. 2015, 54, 4661-4664.

${ }^{34}$ Zhang, H., Lu, Z., ACS Catalysis 2016, 6, 6596-6600.

${ }^{35}$ Jiang, Y., Jiang, J., Zhang, X., J. Am. Chem. Soc. 1998, 120, 3817-3818.

${ }^{36}$ Mc Manus, H. A., Guiry, P. J., J. Org. Chem. 2002, 67, 8566-8573.

${ }^{37}$ Lu, S.-F., Du, D.-M., Wang, S.-W., Xu, J., Tetrahedron: Asymmetry. 2004, 15, 3433-3441.

${ }^{38}$ Du, D.-M., Lu, S.-F., Fang, T., Xu, J., J. Org. Chem. 2005, 70, 3712-3715.

${ }^{39}$ Nishiyama, H., Furuta, A., Chem. Commun. 2007, 760-762.

${ }^{40}$ Inagaki, T., Phong, L. T., Furuta, A., Ito, J.-i, Nishiyama, H., Chem. Eur. J. 2010, 16, 3090-3096.

${ }^{41}$ Inagaki, T., Ito, A., Ito, J., Nishiyama, H., Angew. Chem. Int. Ed. 2010, 49, 9384-9387.

42 Nixon, T. D., Ward, B. D., Chem. Commun. 2012, 48, 11790-11792.

${ }^{43}$ Bennett, S. D., Core, B. A., Blake, M. P., Pope, S. J. A., Mountford, P., Ward, B. D., Dalton Trans. 2014, 43, 5871-5885. 
${ }^{44}$ Bauer, G., Cheung, C. W., Hu, X., Synthesis 2015, 47, 1726-1732.

${ }^{45}$ Li, C., Liu, F.-L., Zhou, Y.-Q., Chen, J.-R., Xiao, W.-J., Synthesis 2013, 45, 601-608.

${ }^{46}$ Chu, J. C. K., Dalton, D. M., Rovis, T., J. Am. Chem. Soc. 2015, 137, 4445-4452.

${ }^{47}$ Lei, G., Zhang, H., Chen, B., Xu, M., Zhang, G., Chem. Sci. 2020, 11, 1623-1628.

${ }^{48}$ Mo, X., Chen, B., Xu, M., Zhang, G., Angew. Chem. Int. Ed. 2020, 59, 13998-14002.

${ }^{49}$ Inoue, M., Suzuki, T., Nakada, M., J. Am. Chem. Soc. 2003, 125, 1140-1141.

${ }^{50}$ Inoue, M., Nakada, M., J. Am. Chem. Soc. 2007, 129, 4164-4165.

${ }^{51}$ Inoue, M., Nakada, M., Org. Lett. 2004, 6, 2977-2980.

${ }^{52}$ Deng, Q.-H., Wadepohl, H., Gade, L. H., Chem. Eur. J. 2011, 17, 14922-14928.

${ }^{53}$ Deng, Q.-H., Wadepohl, H., Gade, L. H., J. Am. Chem. Soc. 2012, 134, 2946-2949.

${ }^{54}$ Bleih, T., Deng, Q.-H., Wadepohl, H., Gade, L. H, Angew. Chem. Int. Ed. 2016, 55, 7852-7856.

${ }^{55}$ Qiu, J., Wu, D., Karmaker, P. G., Qi, G., Chen, P., Yin, H., Chen, F.-X., Org. Lett. 2017, 19, 4018-4021.

${ }^{56}$ Bleih, T., Wadepohl, H., Gade, L. H, J. Am. Chem. Soc. 2015, 137, 2456-2459.

${ }^{57}$ Bleih, T., Gade, L. H, J. Am. Chem. Soc. 2016, 138, 4972-4983.

${ }^{58}$ Blasius, C. K., Vasilenko, V., Gade, L. H, Angew. Chem. Int. Ed. 2018, 57, 10231-10235.

${ }^{59}$ Blasius, C. K., Heinrich, N. F., Vasilenko, V., Gade, L. H, Angew. Chem. Int. Ed. 2020, 59, 15974-15977.

${ }^{60}$ Vasilenko, V., Blasius, C. K., Wadepohl, H., Gade, L. H, Angew. Chem. Int. Ed. 2017, 56, 8393-8397.

${ }^{61}$ Vasilenko, V., Blasius, C. K., Gade, L. H, J. Am. Chem. Soc. 2018, 140, 9244-9254.

${ }^{62}$ Blasius, C. K., Wadepohl, H., Gade, L. H, Eur. J. Inorg. Chem. 2020, 2335-2342.

${ }^{63}$ Clarke, M. L., Diaz-Valenzuela, M. B., Slawin, M. Z., Organometallics 2007, 26, 16-19.

${ }^{64}$ Diaz-Valenzuela, M. B., Phillips, S. D., France, M. B., Gunn, M. E., Clarke, M. L., Chem. Eur. J. 2009, 15, 1227-1232.

${ }^{65}$ Phillips, S. D., Andersson, K. H. O., Kann, N., Kuntz, M. T., France, M. B., Wawrzyniak, P., Clarke, M. L., Catal. Sci. Technol. 2011, 1, 1336-1339.

${ }^{66}$ Fuentes, J. A., Phillips, S. D., Clarke, M. L., Chemistry Central J. 2012, 6, 151.

${ }^{67}$ Fuentes, J. A., Carpenter, I., Kann, N., Clarke, M. L., Chem. Commun. 2013, 49, 10245-10247.

${ }^{68}$ Xie, J.-H., Liu, X.-Y., Xie, J.-B., Wang, L.-X., Zhou, Q.-L, Angew. Chem. Int. Ed. 2011, 50, 7329-7332.

${ }^{69}$ Yan, P.-C., Zhu, G.-L., Xie, J.-H., Zhang, X.-D., Zhou, Q.-L, Li, Y.-Q., Shen, W.-H., Che, D.-Q., Org. Process Dev.. 2013, 17, 307-312. 
${ }^{70}$ Zhu, G.-L., Zhang, X.-D., Yang, L.-J., Xie, J.-H., Che, D.-Q., Zhou, Q.-L, Yan, P.-C., Li, Y.-Q., Org. Process Dev.. 2016, 20, 81-85.

${ }^{71}$ Xie, J.-H., Liu, X.-Y., Yang, X.-H., Xie, J.-B., Wang, L.-X., Zhou, Q.-L., Angew. Chem. Int. Ed. 2012, 51, 201-203.

${ }^{72}$ Yang, X.-Y., Xie, J.-H., Liu, W.-P, Zhou, Q.-L., Angew. Chem. Int. Ed. 2013, 52, 7833-7836.

${ }^{73}$ Yan, P.-C., Xie, J.-H., Zhang, X.-D., Chen, K., Li, Y.-Q., Zhou, Q.-L., Che, D.-Q., Chem. Commun. 2014, 50, 15987-15990.

${ }^{74}$ Yang, X.-Y., Yue, H.-T., Yu, N., Li, Y.-P., Xie, J.-H., Zhou, Q.-L., Chem. Sci.. 2017, 8, 1811-1814.

${ }^{75}$ Liu, W.-P, Yuan, M.-L., Yang, X.-H., Li, K., Xie, J.-H., Zhou, Q.-L., Chem. Commun. 2015, 51, 6123-6125.

${ }^{76}$ Chen, G.-Q., Lin, B.-J., Huang, J.-M., Zhao, L.-Y., Chen, Q.-S., Jia, S.-P., Yin, Q., Zhang, X., J. Am. Chem. Soc. 2018, 140, 8064-8068.

${ }^{77}$ Nie, H., Zhou, G., Wang, Q., Chen, W., Zhang, S., Tetrahedron: Asymmetry. 2013, 24, 1567-1571.

${ }^{78}$ Widegreen, M. H., Harkness, G. J., Slawin, A. M. Z., Cordes, D. B., Clarke, M. L., Angew. Chem. Int. Ed. 2017, 56, 5825-5828.

${ }^{79}$ Ling, F., Chen, J., Nian, S., Hou, H., Yi, X., Wu, F., Xu, M., Zhong, W., Synlett 2020, 31, 285-289.

${ }^{80}$ Hu, X., Dai, H., Bai, C., Chen, H., Zheng, Z., Tetrahedron: Asymmetry. 2004, 1, 1065-1068.

${ }^{81}$ Zhang, C., Hu, X.-H., Wang, Y.-H., Zheng, Z., Xu, J., Hu, X.-P., J. Am. Chem. Soc. 2012, 134, 9585-9588.

${ }^{82}$ Li, L., Liu, Z.-T., Hu, X.-P., Chem. Commun. 2018, 54, 12033-12036.

${ }^{83}$ Zhu, F.-L., Wang, Y.-H., Zhang, D.-Y., Xu, J., Hu, X.-P., Angew. Chem. Int. Ed. 2014, 53, 1410-1414.

${ }^{84}$ Zhang, C., Wang, Y.-H., Hu, X.-H., Zheng, Z., Xu, J., Hu, X.-P., Adv. Synth. Catal. 2012, 354, 2854-2858.

${ }^{85}$ Wei, D.-Q., Liu, Z.-T., Wang, X.-M., Hou, C.-J., Hu, X.-P., Tetrahedron Lett. 2019, 60, 151305.

${ }^{86}$ Zhu, F.-L., Wang, Y.-H., Zhang, D.-Y., Xu, J., Hu, X.-P., Angew. Chem. Int. Ed. 2014, 53, 10223-10227.

${ }^{87}$ Han, F.-Z., Zhu, F.-L., Wang, Y.-H., Zou, Y., Hu, X.-H., Chen, S., Hu, X.-P., Org. Lett. 2014, 16, 588-591.

${ }^{88}$ Wang, B., Liu, C., Guo, H., RSC Adv. 2014, 4, 53216-53219.

${ }^{89}$ Zhang, C., Hui, Y.-Z., Zhang, D.-Y., Hu, X.-P., RSC Adv. 2016, 6, 14763-14767.

${ }^{90}$ Xia, J.-T., Hu, X.-P., Org. Lett. 2020, 22, 1102-1107.

${ }^{91}$ Xu, H., Laraia, L., Schneider, L., Louven, K., Strohmann, C., Antonchick, A. P., Waldmann, H., Angew. Chem. Int. Ed. 2017, 56, 11232-11236.

92 Shao, L., Hu, X.-P., Org. Biomol. Chem. 2017, 15, 9837-9844. 
${ }^{93}$ Shao, L., Wang, Y.-H., Zhang, D.-Y., Xu, J., Hu, X.-P., Angew. Chem. Int. Ed. 2016, 55, 5014-5018.

${ }^{94}$ Shao, L., Hu, X.-P., Chem. Commun. 2017, 53, 8192-8195.

${ }^{95}$ Ling, F., Hou, H., Chen, J., Nian, S., Yi, X., Wang, Z., Song, D., Zhong, W., Org. Lett. 2019, 21, $3937-3941$.

${ }^{96}$ Wu, W., Liu, S., Duan, M., Tan, X., Chen, C, Xie, Y., Lan, Y., Dong, X.-Q., Zhang, X., Org. Lett. 2016, 18, $2938-2941$

${ }^{97}$ Wu, W., Xie, Y., Li, P., Li, X., Liu, Y., Dong, X.-Q., Zhang, X., Org. Chem. Front. 2017, 4, 555-559.

${ }^{98} \mathrm{Hu}, \mathrm{Y} ., \mathrm{Wu}, \mathrm{W} .$, Dong, X.-Q., Zhang, X., Org. Chem. Front. 2017, 4, 1499-1502.

${ }^{99}$ Qin, C., Chen, X.-S., Hou, C.-J., Liu, H., Liu, Y.-J.., Huang, D.-Z., Hu, X .-P., Synth. Commun. 2018, 48, $672-676$.

${ }^{100}$ Jiang, Y., Jiang, Q., Zhu, G., Zhang, X., Tetrahedron Lett. 1997, 38, 215-218.

${ }^{101}$ Ghorai, S., Chirke, S. S., Xu, W.-B., Chen, J.-F., Li, C., J. Am. Chem. Soc. 2019, 141, 11430-11434.

${ }^{102}$ Ghorai, S., Chirke, S. S., Xu, W.-B., Chen, J.-F., Li, C., Org. Lett. 2020, 22, 3519-3523.

${ }^{103}$ Chen, J.-F., Li, C., Org. Lett. 2020, 22, 4686-4691.

${ }^{104}$ Lagiditis, P.O., Sues, P. E., Sonnenberg, J. F., Wan, K. Y., Lough, A. J., Morris, R. H., J. Am. Chem. Soc. 2014, 136, 1367-1380.

${ }^{105}$ Sonnenberg, J. F., Lough, A. J., Morris, R. H., Organometallics. 2014, 33, 6452-6465.

${ }^{106}$ Sonnenberg, J. F., Wan, K. Y., Sues, P. E., Morris, R. H., ACS Catal. 2017, 7, 316-326.

${ }^{107}$ Smith, S. A. M., Lagiditis, P.O., Lüpke, A., Lough, A. J., Morris, R. H., Chem. Eur. J. 2017, 23, 7212-7216.

108 Seo, C. S. G., Tannoux, T., Smith, S. A. M., Lough, A. J., Morris, R. H., J. Org. Chem. 2019, 84, 1204012049.

${ }^{109}$ Zirakzadeh, A., Kirchner, K., Roller, A., Stöger, B., Widhalm, M., Morris, R. H., Organometallics. 2016, 35 , 3781-3787.

110 Zirakzadeh, A., de Aguiar, S. R. M. M., Stöger, B., Widhalm, M., Kirchner, K., ChemCatChem 2017, 9, 1744-1748.

${ }^{111}$ Garbe, M., Junge, K., Walker, S., Wei, Z., Jiao, H., Spannenberg, A., Bachmann, S., Scalone, M., Beller, M., Angew. Chem. Int. Ed. 2017, 56, 11237-11241.

${ }^{112}$ Garbe, M., Wei, Z., Tannert, B., Spannenberg, A., Jiao, H., Bachmann, S., Scalone, M., Junge, K., Beller, M., Adv. Synth. Catal. 2019, 361, 1913-1920.

${ }^{113}$ Bao, D.-H., Wu, H.-L., Liu, C.-L., Xie, J.-H., Zhou, Q.-L., Angew. Chem. Int. Ed. 2015, 54, 8791-8794. 
${ }^{114}$ Bao, D.-H., Gu, X.-S., Xie, J.-H., Zhou, Q.-L., Org. Lett. 2017, 19, 118-121.

${ }^{115}$ Pastor, I. M., Västilä, P, Adolfsson, H., Chem. Commun. 2002, 2046-2047.

${ }^{116}$ Pastor, I. M., Västilä, P, Adolfsson, H., Chem. Eur. J. 2003, 9, 4031-4045.

${ }^{117}$ Bogevig, A., Pastor, I. M., Adolfsson, H., Chem. Eur. J. 2004, 10, 294-302.

118 Västilä, P., Wettergren, J., Adolfsson, H., Chem. Commun. 2005, 4039-4041.

${ }^{119}$ Västilä, P., Zaytsev, A. B., Wettergren, J., Privalov, T., Adolfsson, H., Chem. Eur. J. 2006, 12, 3218-3225.

${ }^{120}$ Wettergren, J., Buitrago, E., Ryberg, P., Adolfsson, H., Chem. Eur. J. 2009, 15, 5709-5718.

${ }^{121}$ Wettergren, J., Zaytsev, A. B., Adolfsson, H., Adv. Synth. Catal. 2007, 349, 2556-2562.

${ }^{122}$ Coll, M., Pàmies, O., Adolfsson, H., Dieguez, M., Chem. Commun. 2011, 47, 12188-12190.

${ }^{123}$ Coll, M., Ahlford, K., Pàmies, O., Adolfsson, H., Dieguez, M., Adv. Synth. Catal. 2012, 354, 415-427.

${ }^{124}$ Margalef, J., Slagbrand, T., Tinnis, F., Adolfsson, H., Dieguez, M., Pàmies, O., Adv. Synth. Catal. 2016, 358, 4006-4018.

${ }^{125}$ Naganawa, Y., Namba, T., Aoyama, T., Shoji, K., Nishiyama, H., Chem. Commun. 2014, 50, 13224-13227.

${ }^{126}$ Naganawa, Y., Abe, H., Nishiyama, H., Synlett 2016, 27, 1973-1978.

${ }^{127}$ Naganawa, Y., Aoyama, T., Nishiyama, H., Org. Biomol. Chem. 2015, 13, 11499-11406.

${ }^{128}$ Naganawa, Y., Aoyama, T., Kato, K., Nishiyama, H., ChemistrySelect 2016, 1, 1938-1942.

${ }^{129}$ Korkmaz, N., Astley, D., Astley, S. T , Turk. J. Chem. 2011, 35, 361-374.

${ }^{130}$ Qiang, G. R., Shen, T. H., Zhou, X.-C., An, X.-X., Song, Q.-B., Chirality 2014, 26, 780-783.

${ }^{131}$ Song, Q., An, X., Xia, T., Zhou, X., Shen, T., C. R. Chimie 2015, 18, 215-222.

${ }^{132}$ Romanowski, G., Kira, J., Polyhedron 2013, 50, 172-178.

${ }^{133}$ Romanowski, G., Lis, T., Inorganica Chimica Acta 2013, 394, 627-634.

${ }^{134}$ Romanowski, G., Wera, M., Polyhedron 2013, 50, 179-186.

${ }^{135}$ Romanowski, G., Kira, J., Wera, M., J. Mol. Cat. A : Chem. 2014, 381, 148-160.

${ }^{136}$ Guo, F., Chang, D., Lai, G., Zhu, T., Xiong, S., Wang, S., Wang, Z., Chem. Eur. J. 2011, 17, 11127-11130.

${ }^{137}$ Wang, C., Xu, C., Tan, X., Peng, H., He, H. Org. Biomol. Chem. 2012, 10, 1680-1685.

${ }^{138}$ Boobalan, R., Chen, C., Adv. Synth. Catal. 2013, 355, 3443-3450.

${ }^{139}$ Motoyama, Y., Makihara, N., Mikami, Y., Aoki, K., Nishiyama, H., Chem.. Lett. 1997, 951-952.

${ }^{140}$ Denmark, S. E., Stavenger, R. A., Faucher, A.-M., Edwards, J. P., J. Org.. Chem. 1997, 62, 3375-3389.

${ }^{141}$ Stark, M. A., Richards, C.J., Tet.. Lett. 1997, 38, 5881-5884. 
${ }^{142}$ Nishiyama, H., Chem. Soc. Rev. 2007, 36, 1333-1141.

${ }^{143}$ Ito, J.-i., Nishiyama, H., Top. Organomet. Chem. 2011, 37, 185-205.

${ }^{144}$ Ito, J.-i., Nishiyama, H., Top. Organomet. Chem. 2013, 40, 243-270.

${ }^{145}$ Ubukata, S., Ito, J.-i., Oguri, R., Nishiyama, H., J. Org. Chem. 2016, 81, 3347-3355.

${ }^{146}$ Morisaki, K., Sawa, M., Nomaguchi, J.-y, Morimoto, H., Takeuchi, Y., Mashima, K., Ohshima, T., Chem. Eur. J. 2013, 19, 8417-8420.

${ }^{147}$ Morisaki, K., Sawa, M., Yonesaki, R., Morimoto, H., Mashima, K., Ohshima, T., J. Am. Chem. Soc. 2016, 138, 6194-6203.

${ }^{148}$ Hao, X.-Q., Gong, J.-F., Du, C.-X, Wu, L.-Y., Wu, Y.-J., Song, M. P., Tetrahedron Lett. 2006, 47, 50335036.

${ }^{149}$ Wu, L.-Y., Hao, X.-Q., Xu, Y.-X., Jia, M.-Q., Wang, Y.-N., Gong, J.-F., Song, M. P., Organometallics 2009, 28, 3369-3380.

${ }^{150}$ Hao, X.-Q., Xu, Y.-X., Yang, M.-J., Wang, L., Niu, J.-L., Gong, J.-F., Song, M. P., Organometallics 2012, 31, 835-846.

${ }^{151}$ Hyodo, K, Nakamura, S., Shibata, N., Angew. Chem. Int. Ed. 2012, 51, 10337-10341.

${ }^{152}$ Wang, T., Hao, X.-Q., Huang, J;-J., Niu, J.-L., Gong, J.-F., Song, M. P., J. Org. Chem. 2013, 78, 8712-8721. ${ }^{153}$ Wang, T., Niu, J.-L, Liu, S.-L., Huang, J.-J., Gong, J.-F., Song, M. P., Adv. Synth. Catal. 2013, 355, $927-937$.

${ }^{154}$ Hao, X.-Q., Zhao, Y.-W., Yang, J.-J., Niu, J.-L., Gong, J.-F., Song, M. P., Organometallics 2014, 33, 18011811.

${ }^{155}$ Li, N., Zhu, W.-J., Huang, J.J., Hao, X.-Q., Gong, J.-F., Song, M. P., Organometallics 2020, 39, $2222-2234$. 